\title{
NATIONAL RENEWABLE ENERGY \\ LABORATORY RENEWABLE ENERGY \\ OPPORTUNITY ASSESSMENT FOR USAID \\ MEXICO
}

November 2015

Andrea Watson, Ricardo Bracho, Rachel Romero, Megan Mercer 


\section{NOTICE}

This report was prepared as an account of work sponsored by an agency of the United States government. Neither the United States government nor any agency thereof, nor any of their employees, makes any warranty, express or implied, or assumes any legal liability or responsibility for the accuracy, completeness, or usefulness of any information, apparatus, product, or process disclosed, or represents that its use would not infringe privately owned rights. Reference herein to any specific commercial product, process, or service by trade name, trademark, manufacturer, or otherwise does not necessarily constitute or imply its endorsement, recommendation, or favoring by the United States government or any agency thereof. The views and opinions of authors expressed herein do not necessarily state or reflect those of the United States government or any agency thereof. 


\section{ACRONYMS}

AMDEE

ASOLMEX

BLM

CEADIR

CEL

CEMEX

CENACE

CEWD

CFE

CICC

CONALEP

COP21

CRE

CREZ

EC-LEDS

EE

ERCOT

ETS

GCC

GEM

GHG

GIZ

GOM
Mexican Wind Association

Mexican Association of Photovoltaic Solar Energy

Bureau of Land Management

Climate Economic Analysis for Development, Investment, and Resilience

Clean Energy Certificate

Cementos Mexicanos (National Mexican Cement Company)

National Center for Energy Control

Center for Energy Workforce Development

Federal Electricity Commission

Interministerial Commission on Climate Change

The National College of Technical Professional Education

Conference of Parties 21 (or, the 2015 Paris Climate Conference)

Energy Regulatory Commission

Competitive Renewable Energy Zone

Enhancing Capacity for Low Emission Development Strategies

Energy Efficiency

Electric Reliability Council of Texas

Emissions Trading Scheme

Global Climate Change Office

Gender Equity Model

Greenhouse Gas

Deutsche Gesellschaft fur Internationale Zusammenarbeit (German Society for International Cooperation)

Government of Mexico 


\begin{tabular}{|c|c|}
\hline IEA & International Energy Agency \\
\hline IIE & Instituto de Investigaciones Eléctricas \\
\hline $\mathrm{IMCO}$ & Instituto Mexicano para la Competitividad \\
\hline INDC & Intended Nationally Determined Contribution \\
\hline INECC & National Institute for Ecology and Climate Change \\
\hline Inmujeres & National Institute for Women \\
\hline IREC & Interstate Renewable Energy Council \\
\hline JTA & Job Task Analysis \\
\hline $\mathrm{km}$ & Kilometer \\
\hline $\mathrm{LARCI}$ & Latin America Regional Climate Initiative \\
\hline LSPEE & Public Electricity Service Law \\
\hline LIE & Ley de la Industria Eléctrica (Electricity Industry Law) \\
\hline LTE & Energy Transition Law \\
\hline MDB & Multilateral Development Bank \\
\hline MLED & Mexico Low Emissions Development Program \\
\hline MRV & Measurement, Reporting and Verification \\
\hline Mt CO2e & Million metric ton carbon dioxide equivalent \\
\hline MW & Megawatt \\
\hline NAFIN & Nacional Financiera \\
\hline NREL & National Renewable Energy Laboratory \\
\hline PEACC & Mexican state-level climate action plans \\
\hline POISE & $\begin{array}{l}\text { Programa de Obras e Inversiones en el Sector Eléctrico (Work } \\
\text { Program for Electric Sector Investment) }\end{array}$ \\
\hline PV & Photovoltaic \\
\hline RE & Renewable Energy \\
\hline RUTAS & International Youth Foundation, Mexico \\
\hline
\end{tabular}


SEI

SEN

SEMARNAT

SENER

SEZ

TA

TDY

UCED

UNAM

UNDP

USAID

UVIG
Sustainable Energy Initiative

National Electricity System

Mexican Ministry of Environment and Natural Resources

Mexican Energy Ministry

Solar Energy Zone

Temporada Abierta de Reserva de Capacidad de Transmisión y Transformación de Energía Eléctrica

Temporary Duty Assignment

Unit Commitment and Economic Dispatch

National Autonomous University of Mexico

United Nations Development Programme

United States Agency for International Development

Utility Variable-Generation Integration Group 


\section{TABLE OF CONTENTS}

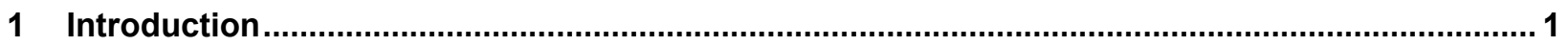

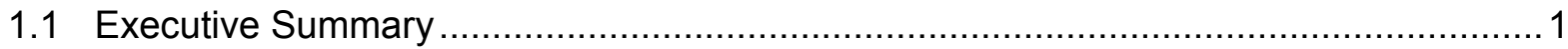

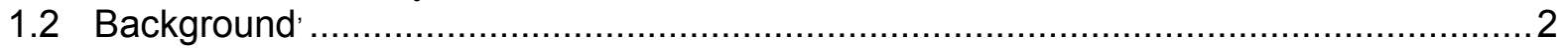

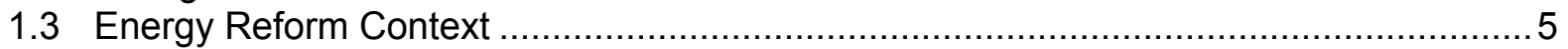

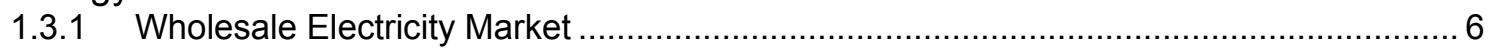

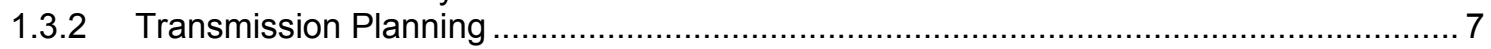

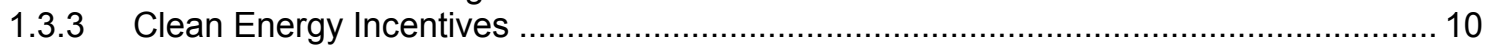

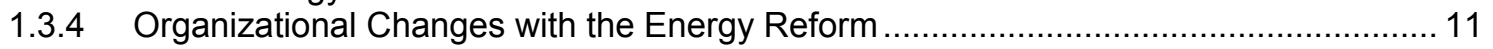

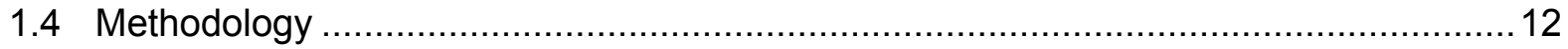

2 Enabling Large-scale Renewable Energy in Mexico: Barriers and Opportunities ....................13

2.1 Building Blocks for Scaling Up Renewable Energy ........................................... 13

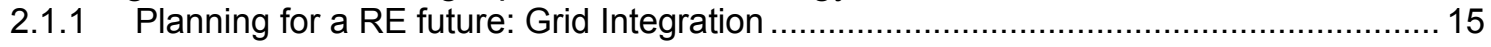

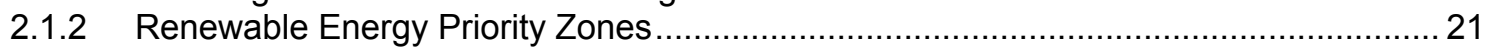

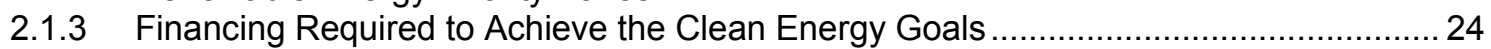

2.1.4 Smart Incentives, Competitive Procurement, and Climate Planning ............................ 29

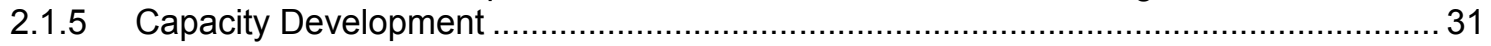

2.1.6 Red de Mujeres en Energía (Women in Energy Network) ........................................... 35

2.2 GHG Emissions and Renewable Energy in Mexico .............................................. 36

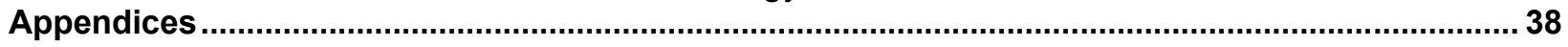

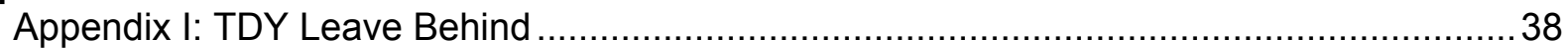

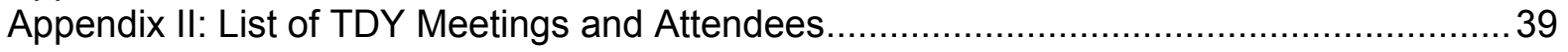

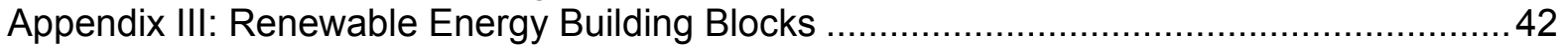

Appendix IV: Grid Integration Check List for Mexico............................................... 44

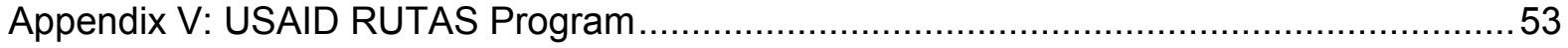




\section{INTRODUCTION}

\section{I.I Executive Summary}

The United States Agency for International Development (USAID) Enhancing Capacity for Low Emission Development Strategies (EC-LEDS) program is designing its second phase of assistance to the Government of Mexico (GOM). In preparation for program design, USAID has asked the National Renewable Energy Laboratory (NREL) to assist in identifying options for enabling renewable ${ }^{1}$ energy in Mexico and reducing greenhouse gas (GHG) emissions in the energy sector.

The NREL team conducted a literature review and consulted with over 20 Mexican agencies and organizations during a two-week temporary duty assignment (TDY) to Mexico to identify gaps, opportunities, and potential program theme areas for consideration by USAID for support to Mexico.

The USAID Global Climate Change Office (GCC) recently introduced informal guidance for USAID renewable energy program design (See Appendix III). GCC recognizes that countries with large amounts of renewable energy deployment (thousands of megawatts $(\mathrm{MW})$ ) achieved these results through a few core pillars, or building blocks, that enable renewable energy. These building blocks align with areas where USAID can effectively inform and support country efforts to advance large-scale renewable energy deployment as a priority pathway for GHG emission reductions. The NREL team considered this building blocks framework as it compiled this renewable energy assessment for Mexico.

Opportunity and program themes are presented for grid planning and integration, locational concentration (renewable energy priority zones), renewable energy finance, and capacity building. Additional projects and gender activities are also identified. A discussion of GHG emissions implications is included. The opportunities and program theme areas are intended to help guide USAID/Mexico as it considers options for new program design. Additional development will be required to evaluate and translate the information presented in this assessment into an actionable program.

USAID has an opportunity to enable renewable energy and help Mexico successfully meet its emission reduction goals by developing a robust, technical, and concentrated approach to one or more of the program theme areas presented here.

\footnotetext{
${ }^{1}$ For the purpose of this document, renewable energy is defined as wind, solar, geothermal, biopower, and smallscale hydropower unless otherwise defined.
} 


\section{I.2 Background ${ }^{2,3}$}

In June 2012, Mexico passed General Climate Change Law, which set forth both a GHG emission reduction goal and a clean energy generation goal of $35 \%$ by 2024 . In early 2013, the Enrique Peña Nieto administration released an updated National Climate Change Strategy, with a vision for the next 10,20, and 40 years for reducing GHG emissions while promoting development and resiliency in Mexico ${ }^{4}$. In April 2014, the Mexican Ministry of Environment and Natural Resources (SEMARNAT) released a revised Special Program on Climate Change for the period 2014 to 2018. The PEACC is more focused policy document for the short-term, derived from the guidance provided in the General Climate Change Law. In addition, Mexican states are developing statelevel climate change action plans (PEACCs), in coordination with the Mexican Ministry of Environment and Natural Resources (SEMARNAT) and the National Institute for Ecology and Climate Change (INECC).

The Mexican Electricity Industry Law or Ley de la Industria Eléctrica (LIE) was enacted on August 11, 2014 and defines clean energies as those energy sources and electricity generation processes whose emissions or waste, where they exist, do not exceed the thresholds established in the guiding regulations ${ }^{5}$. According to the law, clean energy includes electricity generated from the following sources:

a) Wind

b) Solar radiation, in all its forms

c) Ocean energy in its various forms: tidal, ocean thermal, wave and ocean currents and salt concentration gradient

d) Geothermal reservoirs

e) Bioenergy sources, as determined by the Law for the Promotion and Development of Bioenergy

f) Methane and other gases associated with waste disposal sites, livestock farms and wastewater treatment plants, among others

g) Hydrogen through combustion or used in fuel cells, as long as they meet the minimum efficiency established by the Energy Regulatory Commission (CRE) and with the emissions criteria based on the Life Cycle Analysis established by SEMARNAT

\footnotetext{
${ }^{2}$ In addition to citations, information included is from NREL note taking during meetings and recent conversations with government organizations.

${ }^{3}$ Partially Excerpted from the NREL RE Assessment SOW

4 "National Climate Change Strategy 10-20-40 Vision, Federal Government of Mexico" (Inter-ministerial Commission on Climate Change, June 2013), http://mitigationpartnership.net/sites/default/files/encc_englishversion.pdf.

${ }^{5}$ Enrique Peña Nieto and Honorable Congreso de la Unión Mexicano, LEY DE LA INDUSTRIA ELÉCTRICA, 2014, http://dof.gob.mx/nota_detalle.php?codigo=5355986\&fecha=11/08/2014.
} 
h) Hydroelectric plants

i) Nuclear power

j) Agricultural waste and municipal solid waste, when such processing does not generate dioxins and furans or other issues that may affect the health or the environment and meets the Mexican official standards issued by SEMARNAT

k) Efficient cogeneration plants that meet the efficiency criteria issued by the CRE and the emissions standards established by SEMARNAT

I) Sugar mills that meet the efficiency criteria established by the CRE and emissions established by SEMARNAT

m) Thermal power plants with carbon dioxide capture processes and geological storage having an efficiency which is equal or superior in terms of $\mathrm{kWh}$ generated per tonne of carbon dioxide equivalent emitted into the atmosphere than the minimum efficiency set by the CRE and emissions criteria established by SEMARNAT

n) Technologies considered as low carbon technologies accordance with international standards

o) Other technologies that can be determined by the Ministry of Energy (SENER) and the SEMARNAT, based on parameters and standards for energy and water efficiency, emissions and waste generation, direct, indirect or life cycle analysis. ${ }^{6}$

The LIE has left the door open for SEMARNAT to include natural gas combined cycle generation as clean energy. Many experts in Mexico believe it is unlikely that Mexico will actually take advantage of this since there is no global precedent; very few other countries consider this as a clean technology. Nonetheless, the possibility remains unless the Mexican congress passes the Energy Transition Law.

At the time of this assessment report, the Mexican Congress is charged with analyzing and voting on a new law, The Energy Transition Law or Ley de Transición Energética (LTE). Under the LTE, the clean energy definitions remain the same but the law adds a limit of GHG emissions. For a technology to be considered clean, it must emit 100 $\mathrm{kg} / \mathrm{MWH}$ of $\mathrm{GHG}$ emissions or less. Under this proposed law, natural gas generation would not be considered clean energy. The LTE does allow natural gas to continue to be the transition fuel but these plants could not compete for clean energy certificates.

The LTE specifies intermediary clean energy generation goals ( $25 \%$ by 2018 and $30 \%$ by 2021). The law includes the following additional elements:

- Instruments for energy planning based on the renewable energy goals

- Use of smart grids

${ }^{6}$ Ibid. 
- Development of financial instruments

- Establishment of an energy efficiency roadmap

- Restructuring of the energy transition fund

- Development of a roadmap for industrial development

- Mandates to Secretary of Economy to develop a roadmap of the "clean energy value chains"

- Promotion of research and technology development

- Restructuring of the Instituto de Investigaciones Eléctricas (IIE), explicitly including clean energy as one of their research support work

- Legal recognition of the National Centers for Innovation.

According to calculations from the Latin American Regional Climate Initiative (LARCl), the accomplishment of the $35 \%$ clean energy generation and improved energy efficiency mandates in the law would represent a potential reduction of between 95-115 MtCO2e by 2030 in the electricity sector. This mitigation potential represents almost one third of the total GHG mitigation needed by the country to meet its $-30 \% / 2020$ goal mandated in the General Climate Change Law and in its international mitigation commitments. The status of the LTE and the adoption or not of its components will have implications on USAID program design. As USAID undertakes program design, the status of this law should be taken into account.

Through the Energy Reform, Mexico is currently in the process of making the most significant changes to its energy sector in 80 years. In December 2013, Mexico amended its constitution and subsequently passed secondary legislation and new regulations that have reformed the energy structure in Mexico. As a result of this energy reform, the electricity sector, long dominated by the vertically integrated utility, the Federal Electricity Commission (CFE), is being restructured and a new wholesale electricity market will become operational on January 1, 2016.

To implement these new policies, the GOM is rapidly taking on new responsibilities across a spectrum of issues related to climate change and energy reform. For example,

- SEMARNAT is developing a new, mandatory GHG emission registry that will require all emission sources greater than 25,000 tons of $\mathrm{CO}_{2}$-equivalent $\left(\mathrm{CO}_{2} \mathrm{e}\right)$ per year to report and verify $\mathrm{CO}_{2} \mathrm{e}$ emissions annually.

- SENER is working to meet the GOM's stated goal of 35\% electricity generated from clean sources by 2024. This requires new technical capabilities and management techniques for the country's electricity grid, which will experience significantly more variable renewable energy sources entering into the power grid such as solar and wind.

- The CRE is developing new market regulations, including an innovative financial market for Clean Energy Certificates (CELs), to incentivize renewable energy investment and help meet Mexico's clean energy goal.

- The INECC has defined Mexico's intended nationally determined contribution (INDC) and is developing new evaluation procedures for the GOM's climate activities. 
Mexico faces significant challenges in implementing its vision for climate change mitigation and energy reform, including:

- The GOM needs to further develop staff with specialized expertise on various topics, such as carbon markets, renewable portfolio standards, project finance, evaluation, and measurement, reporting and verification (MRV).

- The energy sector requires detailed information on renewable energy resources in the country, more sophisticated modeling and forecasting techniques, and the expertise to rapidly increase and integrate large amounts of renewable energy onto the grid.

- There is a lack of funding for GHG mitigation measures, particularly for communities and small- and medium-sized businesses, as well as a lack of awareness (especially in the banking sector) on the cost-effectiveness of energy efficiency measures.

\section{I.3 Energy Reform Context ${ }^{7}$}

Before the energy reform, the Public Electricity Service Law (LSPEE) gave CFE complete responsibility for planning the National Electricity System (SEN), performing all acts related to providing the electric public service, and the responsibility to carry out all projects and works requiring planning, implementation, operation and maintenance of the SEN. ${ }^{8}$

During this time, CFE expanded by following a state policy that had the goal of providing electricity to every potential consumer in the country. In addition, CFE was required to approve new projects that achieved the lowest short- and long-term costs, while utilizing a discount rate of 12 percent. ${ }^{9}$ As a result of these policies, at the end of 2014, 98 percent of the Mexican population (119.9 million inhabitants) has access to electricity, through a CFE-owned transmission and distribution network that extends 877 kilometers throughout the national territory. ${ }^{10}$

Under the pre-existing industry structure, public electricity service accounted for 86 percent of the total electricity generation in Mexico. Of this generation, CFE was responsible for 67 percent, while independent power producers (IPP), which had to sell their power to CFE accounted for the rest. ${ }^{11}$ Private sector participation outside of the public service was allowed through special permits for cogeneration, generation for export purposes or self-supply power generation. This private sector generation accounted for $14.3 \%$ of power generation in $2014 .{ }^{12}$ Under the pre-energy reform structure, CFE was also responsible for all of the transmission, distribution, and

\footnotetext{
${ }^{7}$ In addition to citations, information included is from NREL note taking during meetings and recent conversations with government organizations.

8 "Programa de Desarrollo Del Sistema Electrico Nacional 2015 to 2029 PRODESEN" (SENER, July 2015), http://sener.gob.mx/res/index/PRODESEN\%202015_2029.pdf.

${ }^{9}$ SENER in a comment to the Baja California Sur report. SENER obtained the information directly from CFE who discussed it several times in various working groups.

10 "Programa de Desarrollo Del Sistema Electrico Nacional 2015 to 2029 PRODESEN."

${ }^{11}$ Percentages taken from the Ibid.

${ }^{12}$ Ibid.
} 
marketing activities of electrical power in Mexico. In addition, CFE controlled the expansion planning and construction of the transmission and distribution networks.

The enactment of the energy reform took into consideration the needs of a new economic environment requiring an optimal balance between competition, innovation, and technological development and the need for diversification of sources of clean and economical energy. The primary goals of the energy reform are to provide electricity at affordable prices for industry, commercial consumers, the countryside and individual families and to promote energy security for Mexico, while increasing system reliability and improving environmental sustainability.

With the 2013 adoption of the Energy Reform and its 2014 subsequent secondary legislation, Mexico pushed to adopt a number of complex changes to their electricity sector-creating a new wholesale electricity market, defining new transmission planning responsibilities, and establishing new clean energy incentives.

\section{I.3.I Wholesale Electricity Market}

Mexico's new wholesale electricity market, which will start on January 2016, and the responsibility for its operations will fall to the newly created independent system operator, Centro Nacional de Control de Energía (CENACE), a former unit of CFE. During the first year of the market operations, SENER will be responsible for conducting the market monitor activities and after the first year, this responsibility will move to $\mathrm{CRE}^{13}$.

Some previously CFE-controlled activities are opening up to private sector participation and investment. The reform makes it easier for private sector generators to build new generation plants. In addition, Mexico enacted specific legislation to grow and regulate the geothermal industry in effort to grow this industry in Mexico. Under this legislation, the government has defined geothermal zones that CFE can explore and is opening other zones to private sector exploration. ${ }^{14}$

In addition to operational control of the new wholesale electricity market, CENACE is responsible for the preparation and submission (to CRE and SENER) of transmission expansion plans. ${ }^{15}$ Preparation of distribution network expansion plans is now the responsibility of each distribution company. For the moment, CFE owns all of the distribution assets, but private sector participation will also be possible in the future.

In the new wholesale market, generators, both from the private sector and the CFE, will submit bids to the wholesale market based on individual operating costs but will also be able to offer the electricity for sale directly to qualified users through the use of bilateral

\footnotetext{
13 “Mexico's Energy Revolution Series: A Liberalized Electricity Sector" (Manatt Jones Global Strategies, April 2015), http:/www.manatt.com/uploadedFiles/Content/5_Insights/White_Papers/MJGS-Mexico-Oil-and-GasExploration-and-Production.pdf.

${ }^{14}$ SENER made the announcement on July 22, 2015.

${ }^{15}$ Ley de la Industria Electrica. 2014. http://dof.gob.mx/nota_detalle.php?codigo=5355986\&fecha=11/08/2014
} 
contracts. ${ }^{16}$ Qualified users that meet a specific consumption threshold can then buy directly from qualified generators or from the wholesale market. This threshold is expected to be $2 \mathrm{MW}$ for the first eight months of the operation of the wholesale market and $1 \mathrm{MW}$ starting on August $12^{\text {th }}, 2016 .{ }^{17}$ One role that remains unchanged is the role of CFE in the distribution grid. While new private distribution companies are expected to eventually access the market, CFE will continue to supply electricity at regulated rates to residential users and small- and medium-sized commercial and industrial users, also called "basic users," ${ }^{18}$ who cannot participate in the wholesale market.

\subsubsection{Transmission Planning}

Before the reform, all activities including operation and planning were carried out by CFE. CFE was in charge of elaborating the Investment Program or Programa de Obras e Inversiones en el Sector Eléctrico (POISE). This Investment Program was revisited on an annual-basis and contained information regarding generating capacity that, according to CFE, was required to meet the forecasted demand. Along with this information, CFE included all information related to transmission infrastructure (including lines and substations) required to maintain the reliable and secure operation of the system. ${ }^{19}$

POISE considered, among other things, the following basic information:

- Demand forecast for a 15 years horizon (based on economic growth as measured by GDP/capita)

- Expected generation capacity to be decommissioned

- Fuel price forecast (coal, oil and natural gas mainly)

- Cost of infrastructure

- Expected private generation projects to be on-line (based on information from CRE).

All infrastructure proposed in the POISE had to be evaluated by the Ministry of Finance (SHCP) and SENER. Under the former legal framework, CFE was obligated to submit to SHCP and SENER an economic and financial analysis in order to assess the cost

\footnotetext{
16 *Note: "Qualified user" refers to and end user such as existing self-supply users, cogeneration users and those participating in import production. Raquel Bierzwinsky. 2014. "Mexico Is Set to Open Its Power Sector - CFE, CENACE, Wholesale Generators, inside-the-Fence, Transmission, Retail, Electricity." Chadbourne, Project Finance Newswire, June.

17 *Note - TRANSITIONAL ARTICLE 15 of the Electricity Industry Law indicates: ."May be included in the registry of Qualified Users: II. Load centers that report a demand equal to or greater than 3 Megawatts, during the first year of implementation of the Electricity Industry Act. This level is then reduced: a) At least to 2 megawatts at the end of the first year of implementation of the Electricity Industry Act, which took place on August $12^{\text {th }}, 2014$, and b) At least to 1 Megawatt at the end of the second year of implementation of the Electricity Industry

Act" Official Diary of the Federation, August $11^{\text {th }} 2014$.

18 *Note: Basic users, or consumers, will not be able to participate in the wholesale market. The CFE will acquire electricity in the auction process to supply to these types of consumers. Raquel Bierzwinsky. 2014. "Mexico Is Set to Open Its Power Sector - CFE, CENACE, Wholesale Generators, inside-the-Fence, Transmission, Retail, Electricity." Chadbourne, Project Finance Newswire, June.

19 "Programa de Desarrollo Del Sistema Electrico Nacional 2015 to 2029 PRODESEN."
} 
effectiveness of projects. The projects that were approved by SHCP and SENER were then published by CFE in the final version of the POISE.

Under the previous framework, CFE used the assistance of CRE only to provide information about permits indicating the expected dates by which projects would be ready to be interconnected to the grid. As a result, CRE's role was passive and the legal framework did not require specific participation by the regulating body. Even though SENER was responsible with SHCP to review the POISE, it was SHCP who had the leading role.

Regarding transmission expansion or upgrades required for deployment of renewable energies, prior to the energy reform, a system called Temporada Abierta de Reserva de Capacidad de Transmisión y Transformación de Energía Eléctrica (TA) or in English, Open Season to Reserve Transmission Capacity and Transformation of the Electric Power (Open Season). Under this scheme, the government allowed private sector participation for financing, design, and construction of the transmission infrastructure, in collaboration with CFE. ${ }^{20}$ The new transmission projects were then given to CFE as the owner.

With the passing of the energy reform and its secondary legislation, the Electric Industry Act (EIA) redefined the roles of CFE, CENACE, CRE and SENER. In the new legal framework the new National Expansion Program is called Programa de Desarrollo del Sistema Eléctrico Nacional (PRODESEN) and is the successor of the POISE.

Specific timelines must to be considered for the planning process. CENACE and the Distribution Companies (currently just CFE) are required to submit to both SENER and CRE, on February of every year, their expansion programs. Then, CRE has 30 business days to provide an opinion to SENER and to ask CENACE and Distribution Companies to make amendments if necessary. After that, SENER has another 30 business days to authorize the PRODESEN. The following figure shows the process to authorize the PRODESEN. ${ }^{21}$

\footnotetext{
20 “Temporadas Abiertas de Reserva de Capacidad de Transmision y Transformacion ." 2012. CRE .http://www.cre.gob.mx/documento/2317.pdf.

21 "Temporadas Abiertas de Reserva de Capacidad de Transmision y Transformacion ." 2012. CRE .http://www.cre.gob.mx/documento/2317.pdf.
} 


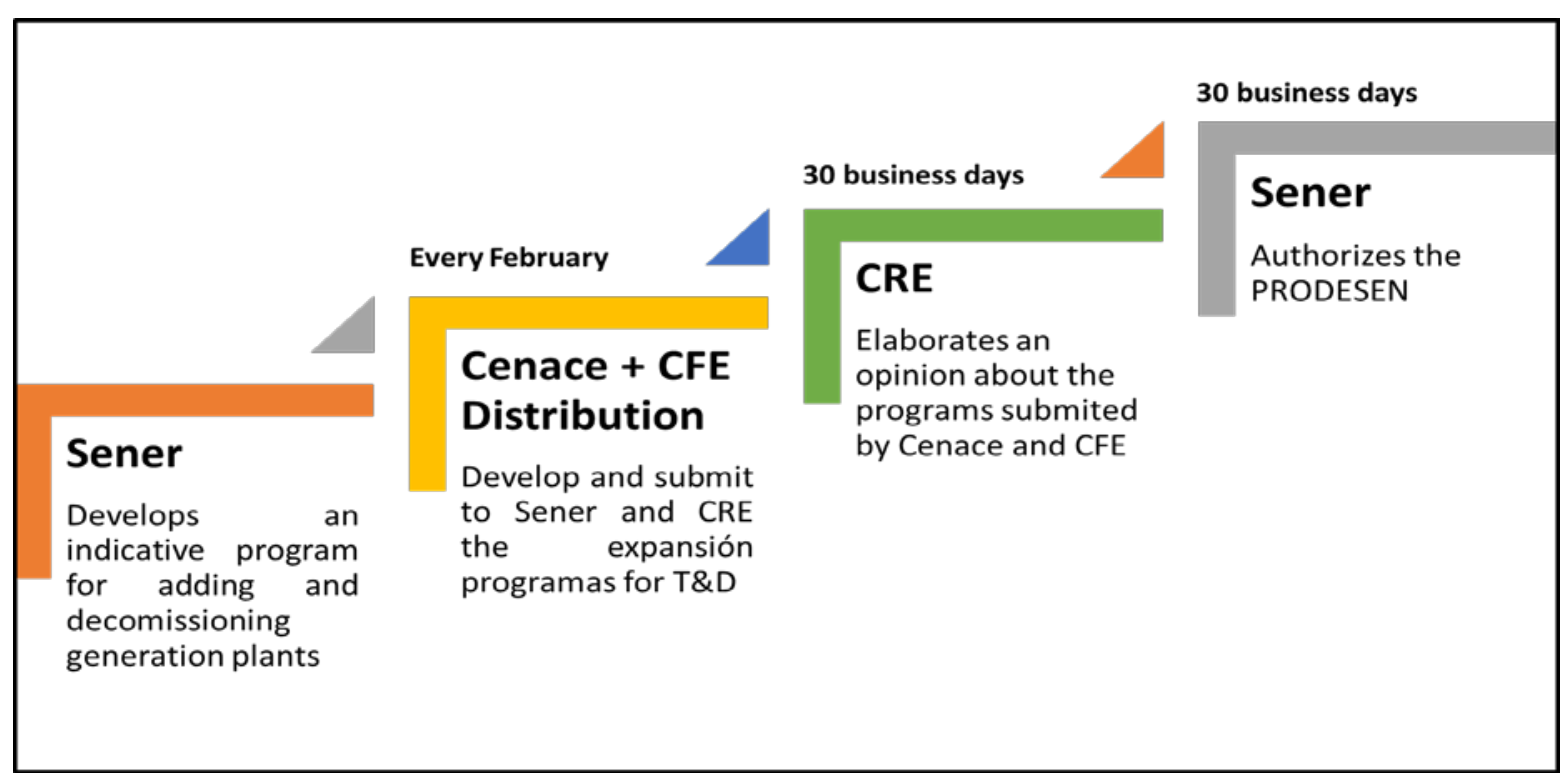

Figure 1: Process to Authorize the PRODESEN ${ }^{22}$

The electricity act now requires the following elements to be contained within the PRODESEN:

- Reliability compliance

- Inclusion of smart grid elements

- Coordination with other programs developed by SENER, such as the "Universal Electrification Fund"

- Development of a mechanism to take into account the opinion of Market Participants

Following the energy reform, when new renewable energy projects require access to new transmission infrastructure, renewable energy developers can request (after providing a series of studies and proof of financial commitment) that CENACE include the new transmission requirements for renewable energy projects into its expansion plan (PRODESEN). With this change, the new transmission infrastructure approved by SENER, would be paid by the government and not by the private sector, which was the case under the TA. ${ }^{23}$

The transmission expansion plans prepared by CENACE now consider, among other things, the optimal generation projects that would meet the demand in the SEN and at the same time help achieve the clean energy objectives within the planning timeframe, the renewable energy potential in various zones of the country, and the infrastructure of the national gas pipeline network. In the near future, the private sector will also be able to participate in financing, building, and owning new transmission infrastructure through

\footnotetext{
22 Source: Comision Reguladora de Energia (CRE)

23 "Ministerio de Electricidad y Energia Renovable." n.d.Ministerio de Electricidad y Energia Renovable.http://www.cenace.org.ec/.
} 
public-private partnerships with CFE. The physical operation of the network will remain in the hands of CFE.

\section{I.3.3 Clean Energy Incentives}

In the past, Mexico has taken a number of actions to promote the use of renewable energy, resulting in one of the fastest growing wind markets in the world in 2009. Some of these actions included the Open Season fixed, low-cost wheeling charges for wind projects; and the energy bank. Major hydroelectric plants, a mature sector, currently make up three-quarters of clean energy production. The hydroelectric growth is expected to mainly come from small hydro projects as some large projects are finding opposition from local communities.

In the PRODESEN, SENER is estimating that in order to meet expected electricity demand growth for the period 2015-2029, 60 GW of additional capacity will be required, with an investment of 653 billion pesos ${ }^{24}$. This additional power capacity is expected to come from conventional technologies (45.7\% or $27,433 \mathrm{MW})$ and $(54 \%$ or $32,552 \mathrm{MW})$ from clean technologies. The estimated composition of the clean technologies include: $37 \%$ wind; $23 \%$ efficient cogeneration; $17 \%$ hydro; $12 \%$ nuclear; $6 \%$ solar and bio energy, and $5 \%$ geothermal. ${ }^{25}$ The new generation projects estimated by technology were formulated by SENER using available data for projects that have been finished but are not yet in operation, projects that are under construction, approved projects, and estimated projects that are under consideration. In reality, the final composition of new projects by 2029 is expected to vary widely from these estimates. ${ }^{26}$ For example, future renewable energy projects will depend largely on the effectiveness of the Clean Energy Certificate market that won't start until 2018. New nuclear capacity is likely to face several obstacles as well.

The government's broad definition of clean energy - certain renewables, but also cogeneration, other low-carbon emissions technologies, future new clean technologies, and existing large hydropower, and nuclear ${ }^{27}$ — may prove somewhat controversial, especially in light of the new clean energy certificates, or CELs, that are replacing the country's two previous types of renewable incentives: the energy bank and the fixed, low-cost wheeling rates (or "postage stamp" rate). ${ }^{28}$ Subsidized wheeling rates were mainly designed for the wind industry as they helped lower the cost of transmission and distribution, so generators were not forced to absorb the interconnection costs of clean energy deployment. ${ }^{29}$ The energy bank was established in 2001 as another way to support the wind industry and decouple energy supply and demand. It allowed self-

\footnotetext{
24 "Programa de Desarrollo Del Sistema Electrico Nacional 2015 to 2029 PRODESEN."

25 "Programa de Desarrollo Del Sistema Electrico Nacional 2015 to 2029 PRODESEN."

${ }^{26}$ As determined through discussions with SENER.

27 *Note: Hydropower and nuclear power are still run through state monopolies. John B. McNeece III. 2015.

"Renewable Energy in Mexico Under the Energy Reform". presented at the Imperial Valley Economic Development Corporation Eighth Annual Renewable Energy Summit, March 12.

${ }^{28}$ Yayoi Sekine. 2015. "Mexico Unveils Power Market Rules, Clean Energy Target". Bloomberg New Energy Finance.

29 “Mexico’s Energy Revolution Series: A Liberalized Electricity Sector.” 2015. White Paper. Manatt Jones Global Strategies.
} 
suppliers to essentially "deposit" excess generation into the bank and "recover" it when their production could not meet their demand. ${ }^{30}$ In the last decade, these incentives and measures arguably promoted renewable energy and cogeneration. Today, they no longer exist in the same form or will be phased out. CELs will emerge as the only renewable energy incentive. ${ }^{31}$

CELs are tradable certificates that wholesale market industry participants will be obligated to obtain. However, draft guidelines under the new law that set forth the framework and criteria for granting CELs, buying and selling them, and a procedure for establishing the mandate to obtain them are yet to be finalized. ${ }^{32}$ There is a push to level the playing field by relying on market mechanisms to promote development of the least expensive clean energy sources. ${ }^{33}$

\subsubsection{Organizational Changes with the Energy Reform}

The electricity law has brought major changes in the roles and responsibilities of SENER, CENACE, CRE, and CFE. Some of the changes are described below:

- SENER is Mexico's energy ministry and will determine consumption levels in order for an entity to be considered a "qualified consumer." The Ministry will also carry out mechanisms for the diversification of energy sources, security, and the promotion of the use of clean energy. The Ministry is responsible for the final approval of the transmission and expansion plans and has the responsibility for market monitoring activities the first year of operation of the wholesale market.

- CENACE is a separate and independent government entity and the main operator of the wholesale market. The organization will set the spot price for electricity and be responsible for ensuring that demand for electricity is met at the lowest possible cost. ${ }^{34}$ CENACE is responsible for preparing the transmission expansion plans.

- CRE will issue permits for participation in the wholesale market as a buyer or seller of electricity. They will also be responsible for setting tariffs of transmission, distribution, and basic retail services, issuing forms of interconnection contracts, setting general conditions for participants in the wholesale market, and managing CELs. ${ }^{35}$ CRE is responsible for evaluating the transmission and distribution expansion plans provided by CENACE and the distribution companies. This

\footnotetext{
${ }^{30}$ Stacey Davis, Mark Houdashelt, and Ned Helme. 2012. "Case Study: Mexico's Renewable Energy Program". Center for Clean Air Policy.

${ }^{31}$ Yayoi Sekine. 2015. "Mexico Unveils Power Market Rules, Clean Energy Target.” Bloomberg New Energy Finance.

${ }^{32}$ Yayoi Sekine. 2015. “Mexico Unveils Power Market Rules, Clean Energy Target.” Bloomberg New Energy Finance.

33 “Mexico's Energy Revolution Series: A Liberalized Electricity Sector.” 2015. White Paper. Manatt Jones Global Strategies.

${ }^{34}$ Raquel Bierzwinsky. 2014. "Mexico Is Set to Open Its Power Sector - CFE, CENACE, Wholesale Generators, inside-the-Fence, Transmission, Retail, Electricity." Chadbourne, Project Finance Newswire, June.

${ }^{35}$ Jorge Alvarez, Fabián Valencia. 2015. "Made in Mexico: Energy Reform and Manufacturing Growth". Working Paper. International Monetary Fund.
} 
evaluation will use a cost benefit analysis including reliability and flexibility measures, and the other benefits such as environmental. CRE is also responsible for market monitoring activities of the wholesale power market after the first year of operation.

- CFE will continue to supply an electrical service at regulated rates to residential users and small and medium-sized commercial and industrial users, also called "basic users." CFE is responsible for the physical management of the electric network and with other future distributors, must submit to CRE and SENER, its distribution network expansion plans ${ }^{36}$.

\section{I.4 Methodology}

The following steps were taken to identify gaps and opportunities to support Mexico in a transition to a lower emission electricity sector through renewable energy development:

- Literature review looking at recent documents ( 2012 to current work) to understand the written research and recommendations to start the assessment. Topics included:

- Energy Reform law, analysis of reform, and requirements to meet the reform

- Electricity Industry Law (LIE)

- Energy Transition Law (LTE)

- Market mechanisms and financing

○ Grid integration

- Renewable energy and energy efficiency and associated analysis for Mexico

- The NREL team, with two USAID team members, met with key stakeholders over ten days in Mexico City. During the visit, the team met with the GOM, private stakeholders, and other donor country partners. All meeting attendees are listed in Appendix II.

- $\quad$ During the visit, the team identified common themes that were discussed during the meetings. In turn, potential program themes were identified as possible priorities for further program consideration.

- Potential priority program areas were further detailed with technical input from content experts

- Potential topics for in-depth research were determined relative to the prioritized program areas. Some topics were only lightly touched on or not covered because they were not highlighted in the TDY or literature.

\footnotetext{
36 “Mexico’s Energy Revolution Series: A Liberalized Electricity Sector."
} 


\section{ENABLING LARGE-SCALE RENEWABLE ENERGY IN MEXICO: BARRIERS AND OPPORTUNITIES}

This section explores possible program ideas and distinct activities for accelerating large-scale renewable energy in Mexico. Scaling up renewable energy in Mexico will enable continued economic development while reducing GHG emissions. The ideas set forth here are those that emerged through a literature review that included the context of the current energy reform, prior experiences and knowledge NREL gained through years of collaboration with the GOM and other partners, and themes that emerged during the two week in-country renewable energy assessment in May 2015.

\section{I Building Blocks for Scaling Up Renewable Energy}

The USAID GCC recently introduced guidance for USAID renewable energy program design recognizing that countries with large amounts of renewable energy deployment (thousands of megawatts (MW)) achieved these results through several core pillars, or building blocks, that enable renewable energy. These building blocks align with areas where USAID can add value through their programs in countries where achieving largescale renewable energy is a priority pathway for GHG emissions reduction.

The six building blocks identified by GCC are:

- Grid Integration

- Locational Concentration

- Financing Support

- Smart Incentives

- Competitive Procurement of Generation Capacity

- Climate Planning.

A description of each of these building blocks can be found in the source document included in Appendix III. Figure 2 below illustrates the building block concept. 


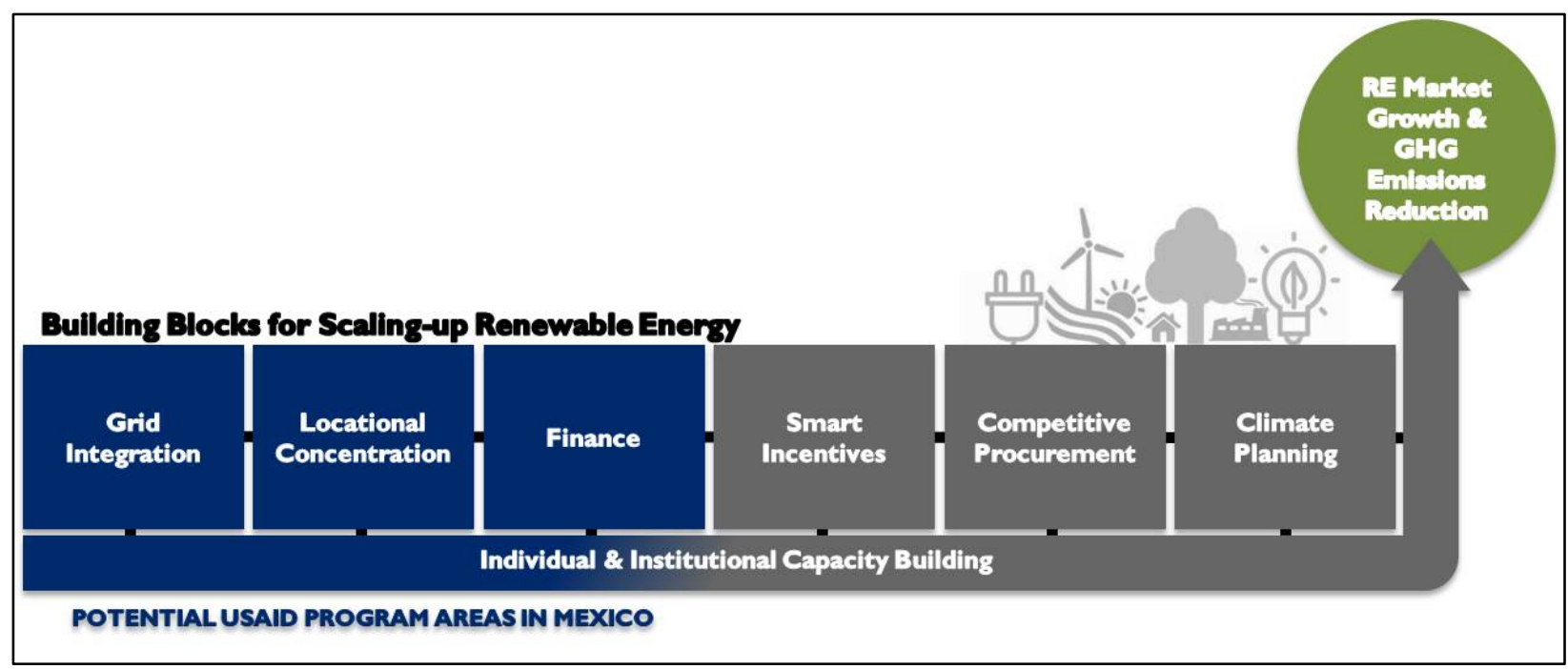

Figure 2: Building Blocks for Scaling up Renewable Energy in Mexico

NREL's Renewable Energy Assessment in Mexico showed that all of the building blocks are important emerging themes in Mexico, especially in the context of the energy reform. Some represent clear areas of opportunity around which new USAID program activities could be designed. In particular, Grid Integration, Locational Concentration, and Financing Support are all areas where addressable barriers were identified.

The incentive scheme and procurement pathway for renewable energy in Mexico were both dramatically reshaped with the recent electricity reform, however a significant amount of uncertainty remains around implementation of both renewable energy procurement and the only remaining incentive (Clean Energy Certificates). This uncertainty will likely last for at least three years or until the CEL market is fully operational.

While there is a near-term opportunity to assist the GOM as they carry-out the reform in these areas, many other donors are helping GOM implement these elements of the reform. Based on this reality, USAID/Mexico may have less immediate impact in this space in 2016 as new program activities are implemented.. One exception may be in the area of incentives for distributed generation which is not addressed by CEL and for which a business model or incentive scheme could be developed ${ }^{37}$.

While climate planning (the last building block) in Mexico is certainly a driver of renewable energy in the country (per the PECC, General Climate Change Law, and recent INDC), the space for high value USAID activities is likely in areas such as carbon markets, MRV, registries, and inventories, which will be addressed in the future Climate Economic Analysis for Development, Investment, and Resilience (CEADIR) assessment.

\footnotetext{
${ }^{37}$ This topic will be further explored in a separate deliverable to USAID Mexico from NREL, which will address distributed generation opportunities and assess the LARCI proposal.
} 


\section{I.I Planning for a RE future: Grid Integration}

Mexico has ambitious clean energy goals. For Mexico to have more renewable energy, the country must optimize the integration of variable renewable energy. The impact of Mexico's clean energy goals will depend partially on Mexico's technical capacity in this area.

Interconnection, variability, and planning were consistently cited challenges during interview meetings. One leader of the solar industry society, the Mexican Association of Photovoltaic Solar Energy (ASOLMEX), stated that perceptions about the variability of solar energy was one of the greatest challenges facing the technology. In addition, the $\mathrm{CRE}$, which is responsible for reviewing long-term grid expansion plans, expressed interest in understanding how to overcome intermittency when incorporating renewable energy into such plans. The Instituto Mexicano para la Competitividad (IMCO) also saw several planning barriers to renewable energy development. It was also mentioned industry uncertainty with regards to how many more megawatts of solar the distribution or transmission system can reliably incorporate. Developing projects and seeking financing without certainty regarding the timing of necessary network upgrades (at the interconnection point or for critical transmission lines) is a challenge.

The literature review further supported these interview insights. Much of the analysis of the electricity reform in Mexico highlights the importance of the new, independent grid operator, CENACE, which is mandated to do expansion planning for the transmission system and to treat all generator types equally. Both Manatt Jones Global Strategies and Bloomberg New Energy Finance have pointed toward a gap in knowledge and human capital at CENACE regarding different aspects of grid operation ${ }^{38}$.

An objective of any electric grid operating system, including Mexico's, is to provide reliable service. Variability is an inherent component of power system operations, due to changes in demand, generator outages, failure to accurately follow dispatch signals, or variations in the underlying resource, as occurs with wind and solar. Some of this variability is reasonably predictable and some is not. Variability is addressed through planned energy scheduling and, for unpredicted variability, ancillary services (e.g., utilizing partially loaded, fast-response generation (such as hydro or gas generators)). Solar and wind energy contribute to this variability, but in most systems their addition does not fundamentally change how the system is operated-the same suite of tools can be used to manage the added variability. Solar and wind generation that is below $5 \%$ or $10 \%$ of total generation are unlikely to affect the types and magnitude of reserves. At higher penetrations (e.g., $30 \%$ of all generation), wind and solar variability can affect the magnitude and timing (response time, duration, seasonality) of spinning and non-spinning reserves. At very high levels (e.g., above $50 \%$ of all generation), considerations will be needed to assess whether new types of reserve products and

\footnotetext{
38 “Mexico's Energy Revolution Series: A Liberalized Electricity Sector."
} 
flexibility mechanisms will be necessary, such as a compensated service to provide primary frequency response. ${ }^{39}$

Focusing on grid integration will help Mexico to most economically include a high percentage of renewable energy in its clean energy mix, while at the same time maintaining reliable system operation. Capacity building, technical assistance, and grid integration studies (both regional and national) are area of potential collaboration between USAID and the GOM. A grid integration study specific to Mexico can be designed to quantify penetration impacts more precisely. Such a study will help identify specific measures that will allow for efficient renewable energy integration. Mexico to most economically include a high percentage of renewable energy in its clean energy mix, while at the same time maintaining reliable system operation.

The role for USAID in Mexico in this area is beyond simply coordinating studies, and instead would be to take an active, substantive role. This role may include coordinating stakeholders, providing technical assistance and advising, assisting with data collection and validation, and capacity building and learning programs.

\section{I.I.I Program Theme}

Assisting Mexico as it plans for its renewable energy future could be a pivotal part of a USAID program of support. As part of this effort, USAID could consider partnering with SENER to lead a full integration study for Mexico. SENER will ultimately lead implementation efforts and decision making, but GOM has expressed a need for a third party coordinator that can take a leadership role in engaging diverse government agencies and stakeholders. Coordinating studies combined with leadership activities, stakeholder collaboration, and an education and outreach campaign would help Mexico reach their clean energy goals with the greatest mix of renewable energy possible and at the lowest cost. As part of the leadership and stakeholder coordinating activities, it may be important that USAID identify the implementation pathways for the application of study results. All activities would be done under the guidance of SENER. Detail on each of these programmatic elements can be found below.

Leadership: Moving toward a more sophisticated analytical framework for grid integration, incorporating results into planning, and identifying implementation pathways will require the ability to bring together and lead diverse stakeholders, technical competence, and the ability to translate technical results into actions. This leadership component is as important as the technical component to maximize results of a USAID program in renewable energy planning and grid integration. While the GOM will ultimately lead implementation efforts and decision making, the GOM has expressed a need for a third party coordinator that can take a leadership role in engaging diverse government agencies and stakeholders. USAID activities, under the guidance of SENER, would likely include coordinating education and outreach, convening stakeholders, seeking in-kind or funding contributions, and shepherding implementation.

\footnotetext{
${ }^{39}$ Parson, Brian et al., "Renewable Electricity Grid Integration Roadmap for Mexico: Supplement to the IEA Expert Group Report on Recommended Practices for Wind Integration" (National Renewable Energy Lab, December 2014).
} 
- Education and outreach: Grid integration is a complex topic. Policy makers may not be intimately aware of the grid impacts of renewable energy policy goals. USAID and others are developing tools and resources to help policy makers and grid operators understand these concepts (e.g., see greeningthegrid.org). A Mexican grid integration program can be designed to make more of these resources available to Mexicans, translated into Spanish, and modified as needed for the Mexican context. Workshops and other resources may need to be developed as well.

- Convening Stakeholders: Identifying the right Mexican stakeholders to participate in a renewable energy and grid integration planning effort will be crucial. The SENER-led Consejo Consultivo para las Energías Renovables ${ }^{40}$, or similar, can be the sort of group to carry forth grid integration studies. Targeting participants from institutions that can lend technical input or data and can also be involved in implementation of results, along with commitment from at least one Mexican organization, likely SENER, to carry studies forward, will ensure that they are modified over time to reflect changes in infrastructure, markets, generation mix, and demand. In addition, the stakeholders can provide input into design and scope of the study, funds, in-kind participation, and data. Coordinating and designing may be appropriate for a donor organization such as USAID, if it can provide the necessary leadership and technical expertise.

In addition, stakeholders may be more engaged and a grid integration study more impactful and better implemented, if the core group of stakeholders have all made commitments to the project's success through funding or in-kind work. CENACE, SENER, and the Instituto de Investigaciones Eléctricas (IIE), for instance, might take a lead role in running models while the National Autonomous University of Mexico (UNAM) and the Danish donor organization supply solar and wind data. Some funding commitment from the government of Mexico would also likely contribute to greater success.

A full grid integration study: According to the International Energy Agency (IEA) Wind Integration Study report, uncertainty about variable renewable energy impact can limit development. Well-executed integration studies and implementation of results can curb uncertainty and lead to the most cost-effective pathway for reaching high penetration levels of variable renewable energy. ${ }^{41}$ In Mexico, the EC-LEDS collaborated with the SENER-led Cosejo Consultivo para las Energías Renovables to develop a grid integration roadmap (Renewable Electricity Grid Integration Roadmap for Mexico). ${ }^{42}$

\footnotetext{
${ }^{40}$ The Consejo is a SENER-led group made up of other Mexican agencies and relevant non-governmental stakeholders including NGOs and non-profits. SENER coordinates analysis, research, and informational workshops that the group used to draft the Special Programs for RE and forthcoming policies, not only from the energy sector but also from other sectors represented at the Council.

41 "IEA Wind Expert Group Report on Recommended Practices 16. Wind Integration Studies" (International Energy Agency, September 12, 2013),

https://www.ieawind.org/index_page_postings/100313/RP\%2016\%20Wind\%20Integration\%20Studies_Approved\% 20091213.pdf.

${ }^{42}$ Parson, Brian et al., "Renewable Electricity Grid Integration Roadmap for Mexico: Supplement to the IEA Expert Group Report on Recommended Practices for Wind Integration.”
} 
The roadmap and the IEA Expert Group Report on Recommended Practices for Wind Integration Studies are excellent resources if USAID chooses to develop a program around grid integration and renewable energy planning. A brief summary of the elements of a full grid integration study is highlighted below and the checklists from the Renewable Electricity Grid Integration Roadmap for Mexico are included in Appendix III.

- Define Scope and Objectives: Prior to starting the full study, planning the execution of the study is an important step to take. Additionally, the creation of stakeholder teams ensures the project moves forward smoothly.

- Input Data: The EC-LEDS program is collaborating with SENER and UNAM to develop solar radiation time series data. This, along with the wind speed data the Danish are developing for Mexico, can be used as input data into a grid integration study. Robust wind input data are based on meso-scale modeling over at least one year with a geographic resolution of $2.5 \mathrm{~km}^{2}$ and a temporal resolution of 5-10 minute intervals, and include development of realistic wind forecasts. In addition, a grid integration program for Mexico would need to seek appropriate sources and collaborators for load data, transmission grid interconnection data, power plant data, and demand side management and storage data.

- Portfolio Development and System Management: Involved renewable energy planning stakeholders, including SENER, CFE, CENACE, and CRE, must define the parameters of a grid integration study for Mexico including a baseline, scenarios for variable renewable energy, conventional generation, demand response and storage, and institutional and market structures.

- Capacity value: Capacity value refers to the contribution a generator makes to meeting peak load. Capacity value of variable renewable energy depends on load profiles, generation mix, and outages. The capacity value of the system, including the identified future percent penetration of variable renewable energy, must be adequate to meet future peak demand. Before launching into further studies, it is important to understand if the proposed scenarios identified in the Portfolio Development Stage will meet peak demand. If not, the scenarios can be reworked before proceeding to other studies.

- Production Costs and Flexibility Assessments: A grid integration study will seek to model operational costs and system flexibility of different variable renewable energy penetration scenarios. System characteristics and responses can be demonstrated through modeling unit commitment and economic dispatch (UCED) ${ }^{43}$ A study such as this requires significant labor to secure input data, run and validate the models, do the analysis, and ensure that the results are technically accurate.

43 “IEA Wind Expert Group Report on Recommended Practices 16. Wind Integration Studies." 
- Transmission Grid Simulations: Load flow and dynamics studies for Mexico would examine scenarios where variable renewable energy production is high and demand is both high and low, as well as scenarios where variable renewable energy production is low and demand is both low and high. In addition, assessing congestion on transmission lines may be particularly important for Mexico and can have impact on renewable energy priority zones.

- Analyzing and Presenting Results: The complexity of power systems makes caution important when interpreting and using the results. Results can be used for initial planning and operation decisions and over time, the studies can be adapted as needed based on real-life feedback.

If stakeholders in both U.S. and Mexican governments are prioritizing expansion of cross-border interconnection, the study could include a look at these interconnection possibilities.

As Mexico emerges from the electricity reform and pursues ambitious emissions reductions goals and plans for integrating more renewable energy, increasingly sophisticated and adaptable grid integration studies will be a foundational analytical tool for planning and implementation.

Forecasting: Forecasting is an important aspect of the renewable energy integration and planning effort. USAID could work with Mexico counterparts to determine a renewable energy forecasting platform. This effort could include elements such as:

- Help CENACE to determine what characteristics of forecasts will benefit system operations and reliability the most. Forecasts can provide a wide range of types of information and can be tuned to different aspects of power generation planning and operational practices at various time scales.

- Characterize forecast errors over larger versus smaller regions to show the value of centralized forecasts.

- Analyze the impact of forecast errors on reserve requirements.

- Facilitate decisions on how to integrate forecasting information into scheduling and dispatch decisions (e.g., at what time frames).

- Help identify pathways to best use and integrate forecasts into Market Design and Grid Operation practices.

Identify and Pursue Intervention Pathways: As the effort of convening a leadership group for comprehensive grid integration study is underway, complementary and concurrent projects that will help maximize variable renewable energy penetration can 
be identified and initiated. Examples of such interventions might include (examples excerpted from the USAID Greening the Grid website): ${ }^{44}$

- Work with CENACE, CRE, and SENER to modernize grid codes and interconnection standards.

- Access demand response as a reserve and provide sufficient incentives for endusers to participate in demand-side management programs.

- Enable demand response to compete on par with supply-side alternatives in utility resource planning and acquisition through mechanisms such as demandside bidding into electricity markets.

- Incentivize more flexibility from current and future generating elements to help support renewable energy integration and assess conventional generation characteristics that will help accommodate renewable energy integration.

- Develop a distributed PV zonal management pilot by:

- Providing technical and regulatory guidance on maintaining reliability on distribution grid (technical parameters of solutions, regulatory frameworks)

- Analyzing the impact of distributed PV on the high-voltage network

- If impacting high-voltage network, advising what type of communications and controls might be necessary, including smart inverter technology

- Consider using pumped storage hydropower optimized to flexibility needs instead of its traditional use as a peak/off-peak resource.

For more examples, see USAID's Grid Integration Toolkit at http://greeningthegrid.org/.

Sustainability: Over the course of developing a renewable energy planning and grid integration study and convening the appropriate stakeholders, a pathway for sustainability can be identified. This will likely occur through institutional capacity building, Mexican counterpart ownership and involvement in the studies, and participation in international fora.

GHG Emissions: By leveraging new technologies and sustainable development best practices from around the world, Mexico has an opportunity to further mitigate GHG emissions and lead the global transformation to cleaner, more efficient energy systems. ${ }^{45}$ Integrating clean energy ${ }^{46}$ into centralized electrical power systems is of

\footnotetext{
44 “Greening the Grid," June 24, 2015, greeningthegrid.org.

${ }^{45}$ According to the Intergovernmental Panel on Climate Change (IPCC), in order to reach a concentration of atmospheric GHG emissions that avoids the worst impacts of climate change, the majority of global climate change emissions mitigation through 2100 relative to the baseline scenario will need to take place in developing countries (IPCC, 2014).
} 
paramount importance to curbing global GHG emissions in developing countries. Relative to deploying decentralized clean energy systems, enhancing the capability of large electricity grids to support high levels of renewable energy generation and demand response has the potential to enable significantly more long-term GHG mitigation in a way that meets future energy demand, while minimizing costs and other negative impacts.

\section{I.I.2 Other Stakeholder Activity}

Grid planning and integration work in Mexico is a clear need and a very large undertaking. Therefore and appropriately there are many other groups working in this area. As mentioned previously, the Danish are involved in wind resource data collection. LICORE and LARCI are involved in smart grid and distributed generation. GIZ is also working some in this area through collaborations with SENER and CRE. The U.S. Department of Energy is also working with the government of Mexico directly through a high level climate and energy agenda. The World Bank through the Energy Sector Management Assistance Program (ESMAP) is providing some technical assistance to Mexico regarding pump storage technologies. The Inter-American Development Bank (IDB) has provided funding for certain projects and some technical assistance. Various NGOs like the World Wildlife Foundation (WWF) has regional offices in Mexico and works in various climate change programs, its energy program is being restructured and opportunities for collaboration will increase. The International Energy Agency (IEA) is doing work on smart grid evaluation through the International Smart Grid Action Network (ISGAN), an initiative of the Clean Energy Ministerial (CEM). The $21^{\text {st }}$ Century Power Partnership, a multilateral effort of the Clean Energy Ministerial, is also heavily involved in grid integration, planning, and capacity building. There are other international donors like the UK agency for international development and domestic non-for profit organizations and academia working in various areas of clean energy.

This does not mean that the space is over-populated with donor and aid organizations; however, it does suggest that careful coordination and leadership will be required to build coalitions, collaboration, and fit each group's contributions into implementation pathways. This is one of the reasons why leadership was the first item discussed under the program theme area.

\section{I.2 Renewable Energy Priority Zones}

Transmission capacity expansion in Mexico is proposed by CENACE to CRE and SENER and must, according to the PRODESEN, take into consideration among other things, the optimal generation projects that would meet the demand in the SEN and meet the objectives of clean energy in the planning horizon, while also considering the renewable energy potential in Mexico. Nearly $80 \%$ of commercial banks have invested in renewable projects that are $50 \mathrm{MW}$ or larger $^{47}$ and it is likely that financial institutions will continue to favor large-scale renewable energy projects. Yet without transmission

\footnotetext{
${ }^{46}$ Throughout this paper, clean energy refers to energy from renewable sources, as well as end-use energy efficiency measures such as demand response.
} 
and interconnection points, financing is unlikely. To help overcome this barrier, the current law for the use of renewable energy and financing of the energy transition (LAERFTE for its name in Spanish), under article 60, gives SENER the responsibility to prepare and publish the national atlas of feasible areas for developing renewable energy generation projects. With this requirement, SENER is beginning to develop a program to prioritize renewable energy zones in Mexico. The proposed Energy Transition Law (LTE) Article 14-X and 14-XI would maintain the same requirement, with the only difference that these would be called clean energy zones. The LTE also specifies the requirements for the Atlas of RE Priority Zones. As of this writing, the law is under consideration with the Mexican Senate, but has not been passed.

The concept of renewable energy priority zones has been demonstrated in the US in the state of Texas. The electric grid regulated by the Electric Reliability Council of Texas (ERCOT) has world-class wind resources, large population (load) centers, and few barriers to land development. In 2005, the Texas Legislature passed a law to designate transmission for Competitive Renewable Energy Zones (CREZs). The CREZs were selected and electric transmission was prioritized to zones from population centers, which in turn significantly boosted planned wind generation projects in ERCOT. ${ }^{48}$ Overall, the CREZ project combined economic development, development of in-state energy resources, and development of green energy through effective legislation.

Properly executed renewable energy priority zones can enable large-scale renewable energy development to proceed in the most cost-effective manner. Zones are areas that have very high resource availability and enable high capacity factors. The purpose of a REZ activity is to accelerate and right-size the build-out of transmission to these zones. While large-capacity, high voltage transmission lines will be required to access the zones, the new lines can be designed to provide less capacity than the total developable capacity of the zone, spurring private competition in renewable energy development. One large benefit of zone designation is aggregation of ultimate total transmission needs rather than incrementally assessing needs and building multiple lower capacity lines. Higher voltage transmission lines are more economically efficient; the number of transmission corridors is minimized, minimizing environmental impact; and fewer permit proceedings are required.

Before priority renewable energy zone can be identified, study zones that have potential are evaluated. Facilitating conversations with the zone developers (typically a government body or system operator) and the private sector over which study zones would be potential investment areas will help ensure that development and financing will follow after transmission infrastructure is built. It may even be possible to secure development commitments.

While this program theme area follows the grid planning and integration discussion, these two activities are linked. The renewable energy resources assessment and production cost modeling of transmission scenarios discussed in the grid integration

\footnotetext{
${ }^{48}$ Lasher, Warren. 2014. "The Competitive Renewable Energy Zones Process " August 8-14. http://energy.gov/sites/prod/files/2014/08/f18/c_lasher_qer_santafe_presentation.pdf.
} 
section above are inputs to the renewable energy zone discussion. Transmission scenarios may change as renewable energy zones are defined.

\section{I.2.I Program Theme}

At the time of this writing, RE priority zones are not mandated by law, however, regardless of the legal outcome of the LTE, the zone concept could be important in enabling large-scale renewable energy in Mexico. USAID may wish to consider developing a program or program area around the RE priority zone concept. USAID could continue to work with SENER to develop the renewable energy zone concept (some of this work has been initiated under EC-LEDS in 2015), identify study areas, engage the private sector to identify zones, and work with SENER and other stakeholders to develop transmission to identified zones. Elements of a renewable energy priority zone program are detailed below.

Stakeholder Group: At the time of this writing, the USAID sponsored EC-LEDS program already held an initial educational workshop on renewable energy zones (May 2015) and is working with SENER to develop a stakeholder group that would need to be consulted as Priority Renewable Energy Zones were developed. By the time a new USAID EC-LEDS program is developed in Mexico, USAID can consider how to support this stakeholder group.

\section{Zone Development Strategy}

An effective renewable energy zone strategy for Mexico could be based on the following steps. These suggested steps draw heavily from the REZ experience in Texas and further scoping/design would be required for program development tailored to the unique needs in Mexio. When appropriate, a potential lead Mexican organization has been identified in parenthesis.

1. Complete a high resolution renewable energy resource assessment (if not already completed). Ideally, the assessment would model hourly wind and solar output for a typical meteorological year, reflect geospatial differences with enough granularity to identify areas with relatively high capacity factors, and locate known geothermal heat potential. This assessment would inform both the renewable energy zone selection and the grid integration studies.

2. Using information from the renewable energy resource assessment, identify study areas where capacity factors and production profiles are high.

3. Develop environmental screens to exclude known sensitive habitat and terrain features that make project development impractical. Using geographic information system analysis, apply the screens to estimate developable potential in each study area.

4. (SENER) Review Mexican law with respect to the legality of providing preferential transmission access to renewable energy developers who provide early binding financial commitments to project development; design mechanisms by which developers may provide demonstration of commercial interest in a study area. 
5. Conduct an open season where renewable energy developers provide tangible demonstrations of commercial interest in specific study areas using the mechanisms established in step 4.

6. (CENACE) Conduct production cost modeling of transmission scenarios that would interconnect study areas with the highest levels of demonstrated commercial interest. This modeling would be done in conjunction with the grid integration study.

7. (SENER) Select renewable energy zones. (Release developers from any financial commitment to areas that are not selected for zones.)

8. (State/local governments, optional) Identify preferred local development areas within a renewable energy zone, along with local incentives for siting development in these areas.

9. (SENER) Approve a transmission build-out plan for the selected renewable energy zones. (May require additional production cost modeling by CENACE to compare top candidate scenarios.)

Land Access: Land access came up repeatedly during in-country meetings, and, according to IMCO, land access issues currently cause more uncertainty in the renewable energy industry than the lack of prices for CELs. Other stakeholders, including AMDEE, also mentioned land access a complicated issue that can be a barrier. This topic is extremely sensitive and there are many sides to be considered. USAID may wish to explore this topic further as an element in a zone concept.

\subsubsection{Other Stakeholder Activity}

Although the effort is nascent, SENER is already beginning to plan for the creation of renewable energy priority zones. In addition to early EC-LEDS support, the $21^{\text {st }}$ Century Power Partnership was also engaged in the first workshop. As a result of this initial workshop, SENER, working with CFE, has begun forming technology-specific working groups to receive feedback from private sector participants.

ASOLMEX also mentioned working with SENER on a geographical map of solar resource potential to encourage utility scale, ground-mounted solar projects. MLED has been engaging with PWC to develop an action plan to promote the development of utility-scale solar. MLED is assisting with developing this concept, and is pushing for an executive committee with members from SENER, Hacienda, SEMARNAT, and others, to build momentum behind this work.

\subsubsection{Financing Required to Achieve the Clean Energy Goals}

Whether we are discussing electricity generation, transmission infrastructure, storage projects or technology research, Mexico, like other countries looking to deploy large amounts of renewable energy, needs to have a series of appropriate financial programs and mechanisms to enable financing in this sector. As is the case in many other countries, funds are available in Mexico but more work needs to be done to systematically channel those funds to the most appropriate projects. There is an opportunity for USAID to take a lead role and collaborate with public and private sector stakeholders to inform the design of required innovative financing instruments, 
programs, and processes to pool the various sources of financing available, which can provide the different types of financing at the lowest possible rates. Providing technical support to help financiers evaluate these projects, especially those with new technologies or in new areas, will also help achieve this goal.

With respect to renewable energy deployment, in 2004 the government introduced some incentives or mechanisms such as fixed wheeling charges, and in 2006 the government began the open seasons program for renewable energy transmission infrastructure; both of these contributed to make financing of large wind projects a reality. Today, under the energy reform, these incentives and programs are no longer available, leaving Clean Energy Certificates, which will begin in 2018, as the only mechanism to specifically incentivize clean energy generation projects. The final details of how these certificates will work and their expected results are unknown at this time.

With regard to renewable energy transmission projects, project developers can now provide CENACE with various technical studies and proof of economic commitment for the construction of the generation projects, and in turn, CENACE can include the necessary transmission infrastructure projects in the PRODESEN. Now with the energy reform, the new transmission infrastructure for renewable energy projects, which requires large amounts of financing, can have private sector co-investment and coownership with CFE. This is a new, unproven scheme that will require a concerted effort to set the right instruments, processes and procedures to create viable projects, which will sell renewable energy transmission capacity to the system.

For Mexico to reach its clean energy goals, new technology and support projects like smart grid, micro grids, and energy storage infrastructure among others will require private sector financing. These investments will require a coordinated effort from various stakeholders, including research institutions, policy makers, domestic and multilateral development institutions, commercial banks, international donors, industry and academia, to design financing programs and instruments to ensure that funding and technical assistance is available for the projects.

In developing countries, innovative technologies in the power sector, such as some renewable energies, smart grid, energy storage and others previously held under government control such as building of transmission projects, require new supporting policies and special financial and technical support mechanisms. In most cases commercial banks are timid and prefer to wait for development financing to take a lead. Development financing in these areas which plays a significant role to increase financing may use proven and new innovative instruments combined with offering technical grants to help reduce the risks to private sector financiers. Gaps and opportunities in this space include:

- While the government has published in the PRODESEN a list of generation and supporting grid infrastructure projects to be built from 2015 to 2029 (see section 1.4 of this document for the details of this composition), the actual projects that will be built are likely to differ greatly from that list, for various reasons including: 
- This is the first planning exercise under the new energy reform and the wholesale market has not yet started. Future generation projects will be significantly influenced by the results shown from the operation of the new wholesale power market, its participants and the energy prices. As the wholesale market evolves, USAID should have opportunities to assist the GOM to improve its planning practices.

- Second, with respect to renewable energy projects included in the PRODESEN, the current list is likely to be underestimating future new installed generation while indicating long-term projects that may never be built. For example, PRODESEN does not currently include projections for distributed generation, which is expected to be significant, especially from solar and efficient cogeneration technologies. The current list of renewables includes mostly projects that were grandfathered under the previous framework with incentives that were well understood by the financiers and are under development or ready to start development.

The PRODESEN also includes several projects estimated to begin construction way into the future. These include several projects from CFE or other sources not yet known. Some of these projects include large hydro and new nuclear generation that were projected before the energy reform. With the restructuring of CFE, some of these long-term projects may receive modifications or be cancelled. The future of these large projects creates further uncertainty for competing RE projects and related investment.

The uncertainty around the effectiveness of CELs in the short term is negatively influencing the number of RE projects included in the PRODESEN. Until the measurable effectiveness of the CELs program and its impact on prices is shown, it is difficult to accurately estimate the pace of investment and RE deployment in the future. The lack of information of future distributed generation and the uncertainty of the very long-term projects in PRODESEN are clouding the clean energy scenarios and required new investment.. USAID could continue to build local capacity in Mexico to improve its planning processes and provide models used by the industry for better forecasting of renewable energies to include distributed generation scenarios to meet clean energy goals while taking into consideration technical limitations and providing solutions. USAID could also provide added support to review and implement new public policies and regulation, including a review of the CELs program and support the GOM around the creation of priority or competitive renewable energy zones, which will have a strong impact in the development of RE projects in various regions of the country.

- With respect to the promotion of RE technologies or the future auctions for new generation, there is currently no distinction between different clean technologies, except that the energy reform included a specific law for geothermal energy. If a priority for the Government of Mexico, there is an opportunity to work with various 
stakeholders to establish programs and mechanisms to accelerate some technologies or business models in the market. One example could be solar leasing and community solar programs, and modifications to the CELs program to promote certain priority technologies in priority areas.

- Special financing and technical support mechanisms may be needed to move clean energy generation, energy efficiency programs, energy storage infrastructure, and smart grid projects at the state and municipality level. There is an opportunity to assess working with various stakeholders to develop programs and support mechanisms and instruments that could bring innovative solutions. The idea would be to find solutions that could be replicated. There are a number of champions in the clean energy space at the state and municipal level where these mechanisms could be piloted.

- There is a lack of financing mechanisms to assist small size RE generation project developers to achieve low rate financing. While large projects can benefit from economies of scale and stronger interest from financiers, small projects are likely to be considered more risky with higher levelized cost of energy (LCOE) and therefore be less attractive to the large financial institutions. To assist the development of these growing sector, donor programs could provide collaborative assistance with government and commercial banks to implement programs that pool various projects as a single financing opportunity, thus spreading project risk (like the variability of the renewable energy resources) in various locations. Innovative financing instruments complemented with technical assistance could be offered to rapidly increase renewable energy deployment.

- With the elimination of the Open Season, transmission lines specific for renewable energy projects can now be included, after meeting certain conditions, in the PRODESEN. The lines that get approval for construction from SENER will have the opportunity to be built with private sector investment and co-ownership with CFE. Public private partnership models in this sector don't currently exist, and present an opportunity for collaboration to develop the business models, programs and mechanisms based on best practices that could attract private sector investment and be successful in selling renewable energy capacity. Mexico by law offers open access to the electricity network. RE transmission infrastructure that don't get approval for inclusion in the PRODESEN can still be built by the private developers, as part of the RE project, making these projects more expensive and difficult to finance. Assisting these projects with financing solutions could also be an opportunity for donor programs.

- Mexico is an early adopter of some renewable technologies for generation, storage, and grid management. With the opening of the electricity sector to private investment and the creation of the wholesale power market, Mexico is poised to see a large influx of some technologies that may have a limited track record in terms of commercial deployment in the field. As a result, some of these technologies may require expert knowledge for the assessment of their technical and economic viability. Technical assistance programs attached to financing facilities would help lenders make investment decisions and greatly reduce 
investment risk and lower the cost of capital of new technologies in Mexico in these specific cases.

\subsubsection{Program Theme}

As mentioned above, there are numerous opportunities to collaborate with many stakeholders including other donors, domestic and multilateral development banks, commercial banks, and the private sector. There are also opportunities to collaborate with other US projects already in development that are working to find innovative solutions to the financing challenges in this sector. Among others, there are opportunities for assisting in the creation of programs, innovative financial mechanisms, and technical support facilities across the whole spectrum of clean energy in Mexico. This could include among a large variety of opportunities, generation projects from new technologies, transmission infrastructure for renewable energy, energy efficiency programs, energy storage, new business models, smart grid deployment, micro grids, and commercialization of new technologies.

The creation of specific programs and innovative financing mechanisms are beyond the scope of this assessment. If USAID is interested in pursuing any or some of these opportunities, a detailed assessment, working with various stakeholders is recommended.

\section{I.3.2 Other Stakeholder Activity}

Other donors seem very interested and some are already doing specific work and analysis of opportunities in this sector. The United Kingdom government is working with the Latin America Regional Climate Initiative (LARCI), SENER and Hacienda to identify financing mechanisms to accelerate renewable energy. The first task was to have the industry complete a survey to understand the risks and barriers within the industry. ${ }^{49}$ The survey results will then be used to guide next steps for the donors in overcoming financing barriers. Other donors working in Mexico in this space include the German international cooperation agency GIZ, which is assisting the Government of Mexico through various agencies and programs to reduce barriers for finance of sustainable projects.

Regional and multilateral development banks have always played a key role in directly financing or co-financing early projects where commercial banks are not yet comfortable because of the lack of knowledge or the perception of high risk. In the clean energy space, these institutions have funded various studies and have been more active searching for larger opportunities. To fully develop their capabilities, some of these institutions may want to partner with other technical organizations, both local and international, to further develop appropriate instruments and programs for clean energy investment.

Private capital investment represents a very large pool of available funding for clean energy projects in generation, transmission, distribution and commercialization in

\footnotetext{
${ }^{49}$ Mercedes Garcia Fariña. 2015. “Acelerando Las Inversiones En Energías Renovables En México”. 4-28.
} 
Mexico. Other clean energy opportunities will be in energy storage and technical solutions for the integration of variable renewable energies. USAID could potentially collaborate with some of these stakeholders in building the technical capabilities to reduce investment risk and with the implementation of best practices to improve the investment profile of these projects.

\section{I.4 Smart Incentives, Competitive Procurement, and Climate Planning}

The options presented here for a USAID program focused on large-scale renewable energy development have coalesced around the renewable energy planning through grid integration, renewable energy priority zones, and renewable energy finance. At the time of this writing, Mexico is deeply involved in promulgating the energy reform though the energy transition law has not been finalized. Therefore, program options to support smart incentives in Mexico, the competitive procurement process, or climate planning are not clear. Flexibility in the next phase of USAID's work may be wise, because clear needs and gaps may emerge over the coming years. Below is a summary of the state of each of these building blocks (Smart Incentives, Competitive Procurement, and Climate Planning).

\section{I.4.I Smart Incentives}

Smart Incentives are one of the USAID identified building blocks for enabling largescale renewable energy development. As a result of the energy reform in Mexico, there is currently only one renewable energy incentive, Clean Energy Certificates. Issued by the CFE, CELs are tradable certificates that wholesale market industry participants will be obligated to obtain ${ }^{50}$ and are used to demonstrate compliance with consumption requirements of clean energy. The CRE will be responsible for awarding CELs to generators for each MW of clean energy they produce, and every year SENER will establish higher thresholds for including clean energy into the mix. ${ }^{51}$

While the certificates broadly refer to clean energy, which some experts argue does not do enough to target or incentivize renewables, they also provide an additional incentive: the installation of distributed generation from clean energy sources. CELs issued for clean distributed generation will be increased for a clean generator based on the total power losses in the country's electrical power system. ${ }^{52}$

Published market rules for CELs by CRE and/or CENACE are forthcoming and were previously forecasted for June 2015. They will establish the manner in which parties will negotiate CELs through the wholesale power market. The published rules will also establish the procedures for CEL auctions in which other wholesale actors and utilities may participate. ${ }^{53}$

\footnotetext{
${ }^{50}$ Yayoi Sekine. 2015. "Mexico Unveils Power Market Rules, Clean Energy Target”. Bloomberg New Energy Finance.

51 "Mexico's Energy Revolution Series: A Liberalized Electricity Sector." 2015. White Paper. Manatt Jones Global Strategies.

${ }_{52}$ Michael S. Hindus, Eric Save, and John B. McNeece III. 2014. "Mexico’s Guidelines for Clean Energy

Certificates Will Support Renewable Energy Development". Pillsbury.

53 "Mexico Announces Guidelines for Issuance of Clean Energy Certificates." 2014. Nexant.
} 


\subsubsection{Competitive Procurement}

Competitive procurement is a USAID-identified building block to enable renewable energy. The idea is that through competitive procurement, renewable energy prices will be driven down through transparent and competitive procurement processes. In Mexico, the auction process is the competitive way in which new generation is procured. Mexico will soon publish market rules on the process for taking bids and auctioning off CELs. Under current guidelines, long-term auctions for power, clean energy and/or clean energy certificates will be effective for 15 years. ${ }^{54}$ They will allow market participants and suppliers serving residential and small business users (users who, alone, are not able to participate in the wholesale market) to enter into financial contracts for CELs. ${ }^{55}$ Market operations are slated to begin October $2016 .^{56}$

At the time of this writing, many details of the auction process after the energy reform are still being worked out. While multiple opportunities for strategic USAID programing in this area are likely to emerge, at this time it is unclear what might be opportunities in the summer of 2016. The USAID funded Mexico Low Emissions Development MLED program is involved in the roll out of the auction process and is advising the GOM in this process.

\section{I.4.3 Climate Planning}

In June 2012, Mexico approved the General Climate Change Law, which authorized the creation of a voluntary emissions trading scheme (ETS) in the country. With a carbon tax on fossil fuels (natural gas exempted ${ }^{57}$ ), the establishment of a mandatory reporting system through the National Emissions Registry, the submission of its INDC ${ }^{58}$ and steps to reform the energy sector, Mexico may transition to an ETS. ${ }^{59}$ The INDC of Mexico translates previously aspirational commitments into mandatory goals that SEMARNAT anticipates to be met regardless of a robust global market mechanism. However, SEMARNAT also recognizes the importance of such a mechanism to achieve rapid and cost-effective mitigation of carbon emissions. ${ }^{60}$

The type of ETS (including emissions, GHG, and sectors covered), the phases and allocation, the flexibility, and the type of compliance is yet to be released. ${ }^{61}$ The Interministerial Commission on Climate Change ( $\mathrm{ClCC}$ ) will be in charge of enforcing

\footnotetext{
54 “Mexico’s New Electricity Market Guidelines.” 2015. Jones Day.

${ }^{55}$ Michael S. Hindus, Eric Save, and John B. McNeece III. 2014. "Mexico’s Guidelines for Clean Energy Certificates Will Support Renewable Energy Development”. Pillsbury.

56 “Mexico’s New Electricity Market Guidelines." 2015. Jones Day.

${ }^{57}$ Addition from USAID commenter: And hard fuels, such as coke and coal, taxed at about 30 percent of the rate per ton of $\mathrm{CO} 2$ as other fuels.

58 * Note: Intended Nationally Determined Contribution (INDC) is a public outline of what post-2020 climate actions a country intends to take. The INDCs are made in preparation for the U.N. Framework Convention on Climate Change (UNFCCC) Conference of the Parties (COP21) in Paris in December 2015. "What Is an INDC?" n.d. World Resources Institute.http://www.wri.org/indc-definition.

59 "Mexico Announces Guidelines for Issuance of Clean Energy Certificates." 2014. Nexant.

60 "Mexico: Intended Nationally Determined Contribution." n.d.

SEMARNAT.http://www.semarnat.gob.mx/sites/default/files/documentos/mexico indc.pdf.

$61 *$ Note: As of June 1, 2015.
} 
the new ETS law and overseeing the development of the carbon market. ${ }^{62}$ SEMARNAT is clearly advancing a robust market-based mechanism but the details of this mechanism were unclear at the time of the TDY. Opportunities for USAID to participate in Mexico's carbon market will be considered in the assessment CEADIR is compiling.

\subsubsection{Capacity Development}

Across all the activities listed above, capacity development activities could be considered for grid operations and planning, renewable energy finance, and work force development. This will be important for sustainable, long-term growth in renewable energy. Capacity building could be designed for three target audiences: professional; students in higher education; and, workforce development (wage-earners in assembly and installation in the renewable energy industry).

As renewable energy demands increase, there will also be an increase in demand for an associated workforce with advanced competencies in grid operations, planning, and market monitoring, especially related to increased renewable energy integration. Professionals already working in this field may require additional training to most effectively and efficiently incorporate renewable energy.

Development related to changing roles and responsibilities as a result of the energy reform is needed within CFE and CENACE. CRE is responsible for increased oversight of grid planning and grid codes, especially as the energy reform rolls out. In addition, CENACE is the independent grid operator with a coinciding new set of roles and responsibilities. While both these organizations have some expertise in these areas, the new responsibilities combined with the fast pace of change and the timely opportunity to make choices that could maximize the amount of integrated renewable energy, mean that additional or improved human resources are needed. CRE recognizes that training this workforce is a priority.

Mexico is already participating in many bilateral and multilateral energy engagements including the Clean Energy Ministerial. There are additional professional groups and organizations in which Mexican professionals can learn and share their experiences with integrating renewable energy.

If the anticipated renewable energy growth for Mexico becomes a reality, positioning the Mexican workforce to take advantage of job opportunities is important. While these jobs will likely be less numerous than those in other established sectors such as the auto industry or other assembly and manufacturing jobs in Mexico, there is an opportunity to have a Mexican workforce assembling, installing, and maintaining renewable energy. In the US, the Interstate Renewable Energy Council (IREC) ${ }^{63}$ was developed in 1982 to accelerate the renewable energy industry. IREC is known for its credentialing program to drive quality workforce training. IREC has also impacted the workforce by ensuring top-tier training, developing community college programs and more.

62 “What Is an INDC?” n.d. World Resources Institute.http://www.wri.org/indc-definition.

${ }^{63}$ http://www.irecusa.org/ 
Local content rules regarding the percentage of work required to be performed by citizens and energy companies in Mexico remain unclear. The rules create a requirement that private companies source at least $25 \%$ of their supplies locally by 2015 and $35 \%$ by 2025 . However, the legislation provided enough flexibility so that each individual contract does not have to meet the $35 \%$ target. Targeted workforce development initiatives can spur the Mexican clean energy market and enable the domestic private sector to achieve local content rules. Through the development of clean-tech clusters or implementation of loans to retool manufacturing facilities, USAID has the opportunity to help further drive economic growth and foster new clean tech jobs by laying out the skills and experience needed in a variety of career pathways to meet market demands.

The distribution network presents another opportunity to assist the GOM to make smart investments in new technologies that reduce system losses. Technical and nontechnical losses are currently higher than $18 \%$, twice the OECD average ${ }^{64}$ Targeted capacity development for advanced distribution management systems can result in minimized losses, minimized load imbalance, and improved voltage quality. Optimized distribution networks decrease long term operating costs, reduce energy waste, and create a more integrated and flexible network to achieve targets of new renewable energy deployment.

Overall, this topic is the foundation for all of the other topics. Capacity building needs to occur in all of the building blocks for Mexico to achieve long-term success in building the renewable energy industry.

\section{I.5.I Program Theme}

Both from the literature and from in-country meetings, it is clear there is an opportunity to build capacity to support accelerated renewable energy deployment. Before designing a capacity building program, a more thorough gap analysis to identify which specific skill sets are of the highest priority would aid in designing a program to develop those skills.

One process for identifying program design elements that could be utilized is the job task analysis (JTA). A JTA determines the skills and training an employee needs and the resources needed to achieve good performance. The JTA supplies the required process and/or steps to perform a task. After the steps are validated by industry, the JTA becomes a tool for educators to help design curriculums for trainings, programs, and certifications. ${ }^{65}$

\section{Capacity Building for Grid Operations and Planning}

Professionals currently working in CRE, SENER, and CENACE will likely need additional training on new responsibilities as a result of the electricity reform and specifically around renewable energy integration and planning, market design,

\footnotetext{
${ }^{64}$ Mexican Energy Reform, Implications and opportunities in the national electricity network. Price Waterhouse Coopers http://www.pwc.com/es_MX/mx/industrias/archivo/2014-01-mexican-energy-reform-implications.pdf

65 "Job Analysis," Encyclopedia, Wikipedia, (June 21, 2015), https://en.wikipedia.org/wiki/Job_analysis.
} 
dispatch/control practices to best integrate renewable energy. Capacity building in the latter will help Mexico reach its clean energy goals, while maximizing renewable energy use. The need for capacity building will likely be twofold: training for those who are already employed in government institutions and increasing the pipeline of qualified professionals, with the right skill sets, available to work in these organizations.

Professional development for CRE, SENER, and CENACE staff may include workshops, exchanges with international professional institutions, and collaboration on joint projects. In addition, professional groups specific to variable grid integration or other relevant topics may be useful. Mexico has participated in the Utility Variablegeneration Integration Group (UVIG) at least once. Mexico may benefit from joining UVIG as some Canadian utilities have done. UVIG was founded in the United States "in 1989 to provide a forum for the critical analysis of wind and solar technology for utility applications and to serve as a source of credible information on the status of wind and solar technology and deployment." The group specifically looks at integrating intermittent renewable energy and has guided the development of many important and influential documents. Because a wide range of technical people participate, the group shares technical information and pushes learning on this topic forward ${ }^{66}$. In addition to UVIG, Mexico could join IEA wind task 25 to enable worldwide lesson sharing and learning, and take advantage of technical assistance offered through Greening the Grid Program ${ }^{67}$.

In addition to capacity building for those who are already involved in grid operations and planning, there is likely a need to increase the number of professionals entering fields that can support the electricity reform and the increase in energy sector careers (this need was noted anecdotally, but the exact breadth of this need requires further examination). These professionals often need to be very highlight educated with masters or Ph.D. degrees. To increase the number of professionals available to hire, USAID could consider:

- Working with universities and the institutions needing technical assistance to strengthen technical curricula. Exchanges with international universities could also be of benefit.

- Partnering with granting and scholarship organizations to increase the support for the number of students with corresponding interests and skill areas.

\section{Capacity Building for Renewable Energy Finance}

As mentioned in section 2.1.3.2, one opportunity for speeding up the mobilization of finance for clean energy is through the strengthening of the technical capabilities for analyzing the projects and with the application of innovative financial mechanisms and best practices. There is a capacity building opportunity that includes collaborating with various donors working in this space and assisting various government of Mexico institutions including SENER, domestic and multilateral development banks, private

66 "UVIG Home and Join,” Organization, UVIG, (2015), http://uvig.org/newsroom/.

${ }^{67}$ Greening the Grid, http://greeningthegrid.org/ 
sector financiers, CRE, academia, etc. This capacity building opportunity could include building data sources and systems for data sharing, feasibility analysis of new projects, creating networks of experts for sharing knowledge, specific programs for new technologies, etc.

\section{Capacity Building for Assembly, Installation, and Operations and Maintenance}

In 2012 , SENER estimated that by $2020,175,000$ jobs could be created by all renewable energy technologies ${ }^{68}$. For comparison, in 2013 the number of jobs in Mexico related to the auto industry was $675,000^{69}$. While the number of jobs estimated by SENER includes direct and indirect jobs, reviewing the methodology used by SENER can determine if there is a risk of overestimation. Regardless, Mexico has an opportunity to prepare a workforce ready to take advantage of any jobs arising from the assembly, installation, and operation and maintenance of renewable energy facilities.

The first step will be a careful JTA to understand what skills the labor force has that can be transferred to renewable energy jobs versus what skills need to be developed for every step along the assembly, installation, and operations of renewable energy plants. The results of this analysis can inform how to best develop skills in the workforce. Engaging stakeholders, such as developers and operators of renewable energy plants, in this process will help develop buy-in and plan for training that leads to jobs.

There are likely a smaller number of highly specialized jobs in the wind industry. Working with wind developers and organizations such as La Asociación Mexicana de Energía Eólica (AMDEE) can help identify what these jobs are and whether Mexican workers are currently being employed or if foreign workers are brought in to do these jobs. From here, USAID can assess pathways to support the development of highly skilled Mexican workers for the wind industry if needed.

\section{1.5.2 Other Stakeholder Activity}

There is significant donor involvement in capacity building in the renewable energy and energy efficiency areas in Mexico. Organizaciones Populares de Vivienda, run by GIZ, is working in capacity building through vocational programs offered in four areas of renewable energy and five areas of energy efficiency retrofits. One program's emphasis is gender equality and equal access ${ }^{70}$.

GIZ and the Danish are involved in institutional capacity building at SENER and CRE. In some cases, the institutional capacity building includes placing consultants into the institutions. The sustainability of these activities may depend on the timeframe and knowledge transfer between the consultants and the permanent members of the organizations. Using local consultants may be more effective than foreign consultants in terms of sustainability.

\footnotetext{
68 "Renewable Energy and Jobs" (IRENA, December 2013), http://www.irena.org/rejobs.pdf.

${ }^{69}$ Priddle, Alisa and Snavely, Brent, "More Car Manufacturing Jobs Move South, to Mexico," USA Today, June 15, 2015, Web edition, sec. Money, http://www.usatoday.com/story/money/cars/2015/06/15/auto-jobsmexico/71224972/.

${ }^{70}$ From conversations with Ms. Sandra Liliana, GIZ
} 
USAID is currently supporting RUTAS, a vocational training program, which has completed an Energy Sector Labor Market Assessment, Curriculum Assessment, and Bi-national Collaboration (Appendix V).

\section{I.6 Red de Mujeres en Energía (Women in Energy Network)}

\section{I.6.I Context and Barriers}

Gender disparities exist in the energy sector in countries across the globe. The obstacles that women face to secure energy sector jobs vary. For women in impoverished rural areas, barriers to inclusion in the energy landscape are in part a result of energy investments that are made without a gender-informed process. In most cases, investments are not designed to factor in gender sensitivities, which according to the African Development Bank Group, harms women and girls the most, because they are often marginalized socially and economically in areas where energy access is limited. ${ }^{71}$

In Latin America, women face institutional barriers and hurdles in access to training, financing and markets that lead to exclusion from the energy sector and its benefits and vulnerability to factors like the market and prices. ${ }^{72}$ In Mexico, as in other countries, a prominent perspective is that enduring and outdated cultural beliefs keep women from breaking through barriers to higher job growth. In a recent McKinsey survey of Latin American executives, $78 \%$ say their country's culture makes it easier for men than for women to move forward in their careers. ${ }^{73}$

Mexico's energy reform did not specifically indicate gender as an area in which change would be made, and it assumed that women in Mexico may continue to face unique institutional barriers and hurdles in access to training and advancement in the near future.

\subsubsection{Program Theme}

In an effort to decrease the gender gap in energy, a Red de Mujeres en Energía (Women in Energy Network) could be created. The objective would be to create an environment where women can collaborate on bringing women into the energy industry. The group would give women a voice within a technical, male-dominated industry. Events or regular meetings as well as mentorship programs could be elements of this program.

If a priority for the Government of Mexico, USAID could act as a facilitator for these events, providing the invitation to participate to key players, from both the private and government sector. In particular, current leaders would be encouraged to mentor the next generation of energy leaders within their work environment. USAID could work to find local partners (government or private sector entities) that would co-sponsor such events.

\footnotetext{
${ }^{71} \mathrm{http} / /$ www.afdb.org/en/news-and-events/article/process-of-developing-an-ecowas-policy-on-women-and-energykicks-off-13996/

72 http://www.ipsnews.net/2013/03/women-entrepreneurs-face-greater-barriers-in-mexico/

${ }^{73} \mathrm{http}$ ://fortune.com/2014/11/11/in-latin-america-why-women-face-an-iron-ceiling/
} 
Another potential gender focused activity is targeted support on workforce development with CFE to achieve a more customer-focused business model through improvements in billing and customer service. To support USAID's commitment for achieving greater gender equality in energy and infrastructure, this intervention would aim to increase the professional participation by women in a rapidly changing niche in the energy sector. Customer-CFE relationships can be optimized through efforts to deepen segmentation, behavioral demand response and the offering of new customized customer options.

Through training opportunities targeted at women professionals, CFE has the potential to improve gender outcomes while streamlining operations through advanced customer information systems $(\mathrm{CIS})^{74}$.

\section{I.6.3 Other Stakeholder Activity}

GIZ has the mandate to include gender topics in all of its projects. In particular, they are promoting educating women in low-income weatherization and energy retrofits.

The National Institute for Women (Inmujeres) has been running the Gender Equity Model (GEM) Initiative since 2003. ${ }^{75}$ The initiative certified some 300 Mexican organizations or companies as "gender equitable" since 2010. A collaboration opportunity could be sought out between Red de Mujeres en Energía and Inmujeres.

\subsection{GHG Emissions and Renewable Energy in Mexico}

Mexico became the first developing nation to release their climate plan the 2015 United Nations Conference of the Parties (COP21) in Paris. According to Mexico's INDC, "... if Mexico achieves its goal [35\% clean energy by 2035], its 2030 emissions will be 759 megatonnes (Mt) of GHG without international support, or $623 \mathrm{Mt}$ with support."76 The country's INDC commits them to reduce GHG emissions by 22 percent (experiencing peak emissions in 2026), and black carbon by $51 \%$ before 2030 . With international support, reduction is expected to be greater (Figure 3). ${ }^{77}$

\begin{tabular}{|c|c|}
\hline \multicolumn{2}{|c|}{ Mexico's INDC Commitment } \\
\hline $\begin{array}{l}\text { Unconditional } \\
\text { Reduction }\end{array}$ & $\begin{array}{l}\text { Conditional } \\
\text { Reduction }\end{array}$ \\
\hline $\begin{array}{l}25 \% \text { greenhouse gas } \\
\text { emissions reduction by } 2030 \text {, } \\
\text { implying a reduction of } \mathrm{GHG} \\
\text { emissions by } 22 \% \text { and black } \\
\text { carbon by } 51 \% \\
{ }^{*} \text { This also implies a net emissions } \\
\text { peak starting from } 2026\end{array}$ & $\begin{array}{l}40 \% \text { greenhouse gas } \\
\text { emissions reduction by } 2030 \text {, } \\
\text { implying a reduction of GHG } \\
\text { emissions by } 36 \% \text { and black } \\
\text { carbon by } 70 \%\end{array}$ \\
\hline
\end{tabular}

Figure 3: Mexico's INDC Commitment

\footnotetext{
${ }^{74}$ This idea of improving CFE-customer relations was provided by an anonymous USAID reviewer.

75 "Renewable Energy and Jobs." 2013. IRENA.http://www.irena.org/rejobs.pdf.

76 "What Is an INDC?” n.d. World Resources Institute.http://www.wri.org/indc-definition.

77 “Mexico: Intended Nationally Determined Contribution.” n.d. SEMARNAT.
} 
About $67 \%$ of $\mathrm{CO}_{2}$ eq comes from the energy sector. This number includes transportation related emissions, which makes up a little more than half of those emissions, followed by the electricity sector. ${ }^{78}$ Figure 4 is from Mexico's Fifth National Communication and illustrates greenhouse gas emissions by sector.
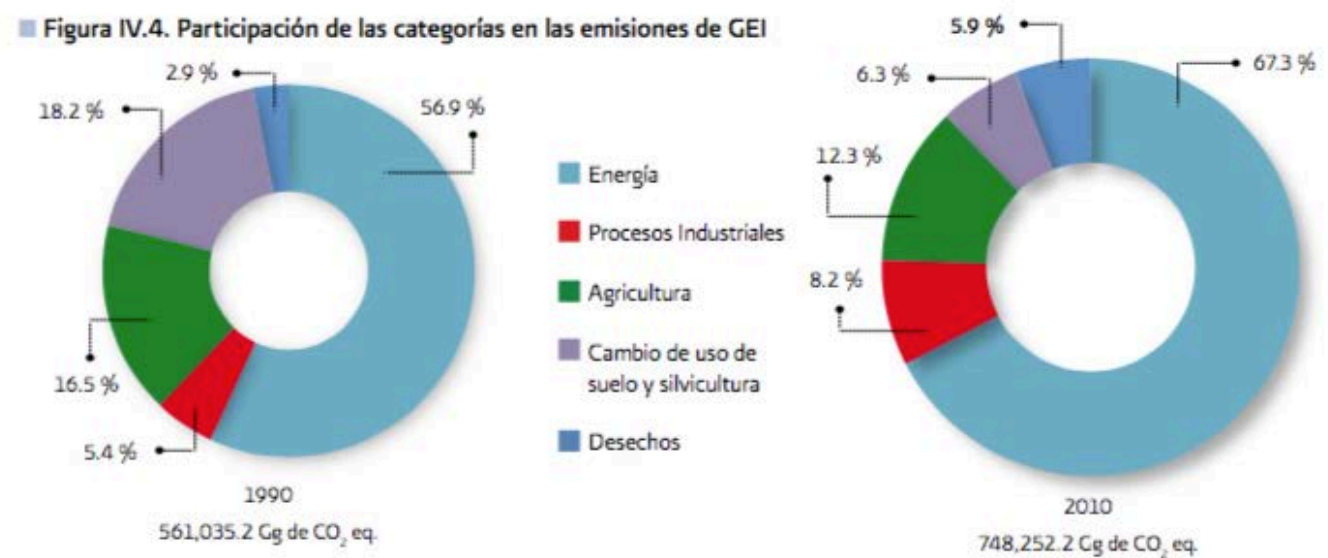

$748,252.2 \mathrm{Cg}_{\mathrm{ge}} \mathrm{CO}_{2}$ eq

Figure 4: GHG emissions by category, from Mexico's Fifth National Communication

\section{GHG Reduction Potential of Proposed Activities}

USAID support could be pivotal in ensuring that Mexico meets its conditional INDC goals. While much of the policy is in place to reach the unconditional goals of the INDC, political will, implementation efficiency, and donor support will likely be crucial to success of meeting the country's conditional goals. The activities included in this RE Assessment Report describe opportunities for USAID to help Mexico contribute to their INDC GHG emission reductions goals through work in the renewable energy sector.

The activities proposed in this document enable renewable energy development in Mexico. We cannot, however, predict how many megawatts of renewable energy (and in turn tons of GHG reduction) will result from these activities. Capacity building at the grid operation and planning professional level could be seen as directly tied to Mexico's ability to maximize integration of variable renewable energy and hence have an impact on emissions reductions.

\footnotetext{
${ }^{78}$ Comisión Intersecretarial de Cambio Climático, "Mexico: Quinta Comunicación Nacional Ante La Convención Marco de Las Naciones Unidas Sobre El Cambio Climático" (SEMARNAT, 2012).
} 


\section{Appendices}

\section{Appendix I: TDY Leave Behind}

\section{Próxima Fase: USAID México, Programa de Cambio Climático}

Mayo, 2015

Junto con el Gobierno de México, USAID México ha trabajado desde hace varios años para mitigar el cambio climático a través de varios programas. Ahora, USAID quiere empezar el proceso de diseñar su próximo programa de cambio climático en México, considerando las políticas relevantes, la reforma energética, y el desarrollo económico del país. Este nuevo programa tendrá una inversión de alrededor de cinco millones de dólares anualmente. A fin de informar este proceso, USAID realizará un análisis enfocado en los temas de energía renovable y eficiencia energética.

Para llevar a cabo este análisis, USAID ha reunido a un equipo de expertos pertenecientes al Laboratorio Nacional de Energía Renovable (NREL) y a la consultoría Abt Associates. El objetivo del análisis es trabajar con el Gobierno de México y otros expertos mexicanos para identificar las estrategias de mayor impacto para la reducción de gases de efecto invernadero.

Los equipos de NREL y Abt Associates efectuarán dos viajes a México con el objetivo de reunirse con los actores más relevantes del sector energético en México. En este primer viaje (11 a 20 de mayo, 2015), el equipo de NREL estará enfocado en el análisis de oportunidades en el sector de energía renovable. Durante el mes de junio, un segundo viaje, integrado por funcionarios de USAID y representantes de Abt Associates se enfocará en eficiencia energética.

Miembros del equipo que realizarán labores de análisis en persona en Mayo:

- Donald McCubbin - Asesor de Medio Ambiente, USAID México (52) 55-4447-9295, dmccubbin@usaid.gov

- Kristen Madler - Coordinadora de Energía Limpia, USAID Washington +1 (202) 712-4295, kmadler@usaid.gov

- Ricardo Bracho - Sr. Program Manager, NREL +1 (303) 514-9512, Ricardo.Bracho@nrel.gov

- Andrea Watson - Manager, NREL +1 (303) 275-4234, andrea.watson@nrel.gov

- Rachel Romero - Ingeniera, NREL +1 (303) 886-8254, rachel.romero@nrel.gov

- Santiago Enriquez - Especialista en Cambio Climático, Abt Associates México (52) 55-5254-2222, Santiago Enriquez@abtmexico.net

El equipo les agradece de antemano su atención y participación. 


\section{Appendix II: List of TDY Meetings and Attendees}

\begin{tabular}{|l|l|}
\hline \multirow{2}{*}{ MLEday, May 11, 2015} \\
\hline & Mrs. Ana Silvia Arrocha \\
\hline & Mr. Mark Oven \\
\hline & Mrs. Ana María Contreras \\
\hline Mr. Ignacio Rodríguez \\
\hline SENER & Mr. Adrian Paz \\
\hline Mr. Efraín Villanueva \\
\hline Mr. Luis Alfonso Muñozcano \\
\hline Mr. Fidel Carrasco Gonzalez \\
\hline \multirow{2}{*}{ ARCI } & Mr. Adrian Fernandez \\
\hline Mr. Jorge Villareal \\
\hline Mr. Juan Carlos Arredondo \\
\hline Mr. Daniel Chacon \\
\hline
\end{tabular}

\section{Tuesday, May 12, 2015}

Dr. Alejandro Peraza Garda

\section{CRE}

\section{SENER}

\section{DANISH}

GIZ

\section{UKE}

Mrs. Norma de la Salud Alvarez Girard

Mr. Martin Llerena Engesser

Mr. David Villalpando

Mr. Efraín Villanueva

Mr. Luis Alfonso Muñozcano

Mr. Fidel Carrasco Gonzalez

Mrs. Ulla Blatt

Mr. Ernesto Feilbogen

Ms. Nicole Taumel

Mrs. Gabriela Rodríguez 


\section{Wednesday, May 13, 2015}

\begin{tabular}{|l|l|}
\hline CFE & Inga. Magaly Flores \\
\hline DOS & Ing. Carlos Sanchez Cornejo \\
\hline SENER & Mr. Pablo Valdez \\
\hline EVENSEN DODGE & Mr. Santiago Creuheras \\
\hline Mr. Adrian Cordero Lovera \\
\hline MLED & Mr. Adolfo Lizarraga \\
\hline
\end{tabular}

Thursday, May 14, 2015

ABM

AMDEE

CESPEDES

UNEP
Mr. Juan Carlos Jiménez

Mr. Héctor J. Treviño

Dra. Luisa Manzanares P.

Ing. Juan manuel Diosdado

Ms. Mercedes Garcia

\section{Friday, May 15, 2015}

\section{IMCO}

INECC

SEMARNAT

MLED
Mr. Rodrigo Gallegos

Dra. Amparo Martinez Arroyo

Dr. Daniel Buira

Ms. Alejandra Lòpez Carbajal

Mr. Rodolfo Lacy

Ms. Monica P. Echegoyen Lopez

Mr. Eduardo Olivares

Mr. Ricardo Troncoso

\section{ABT}

GIZ

\section{Monday, May 18, 2015}

Mr. Santiago Enriquez

Ms. Sandra Liliana 


\section{Tuesday, May 19, 2015}

\section{ASOLMEX}

MLED

\section{Héctor Olea}

Mrs. Ana Silvia Arrocha

Mrs. Ana María Contreras

Mr. Ignacio Rodríguez

Mr. Adrian Paz

US COMMERCIAL SERVICE

Mr. Miguel Angel Vázquez

INDEPENDENT CONTRACTOR

\section{Wednesday, May 20, 2015}

SENER
Mr. Efraín Villanueva

Mr. Luis Alfonso Muñozcano

Mr. Fidel Carrasco Gonzalez 


\section{Appendix III: Renewable Energy Building Blocks ${ }^{79}$}

\section{Building Blocks for Scaling Up Renewable Energy}

Available evidence clearly indicates that the countries that are really scaling up meaning deploying thousands of MW of CE - are using five complementary building blocks:

A. Competition for generation opportunities, often reverse auctions. This drives down prices over time, causing CE to approach parity with thermal generation. Low prices prove attractive to utilities and policy makers, causing more demand for scaling up RE. At some point, CE can even be cheaper than other least cost alternatives, in which case the rationale for more CE becomes even stronger. This isn't theoretical; it's actually what is happening in the west of the US, in India, Germany and the UK.

B. Smart incentives. This means that a country is constantly evolving their incentive regimes for $\mathrm{CE}$, with changes being made to incentive regimes every year or two. Bloomberg New Energy Finance (BNEF) is full of articles on the new incentive regimes in places like China, India, South Africa, Brazil, Mexico, etc. The reason this is important is because countries learn from experience, and the approach to CE evolves as experience is gained. This suggests that support for development and deployment of incentive schemes is advisable.

C. Grid integration. Countries that are really scaling up have realized that they must work on grid integration at the same time as they are scaling up. As they hit capacity levels equal to $8 \%$ to $10 \%$ of total generation capacity, they need to start spending nearly as much on grid integration as on generation capacity. This also has an impact on the prices of CE and on "bankability" of projects. For example, for a period of about 6 years, China curtailed as much as $20 \%$ of their wind capacity because of grid faults due to ramping and lack of evacuation capacity. Curtailment increases the cost of electricity (or lowers returns to investors).

D. Locational concentration. It is important to take locational mapping of RE resources one step further - to planning and executing RE zones. One of the best examples is the Competitive Renewable Energy Zones (CREZ) in Texas. This drives two positive outcomes: (1) it reduces CE prices due to higher capacity factors ${ }^{80}$, and (2) it reduces the costs of common infrastructure per unit by concentrating capacity in limited areas.

E. Financing support. Many countries have created special financing facilities, banks and mechanism to scale up RE. Examples include taxes on fossil fuels used to pay production credits and FITs, and specialized windows in public infrastructure banks, among others. In many countries the financing support is needed to overcome the risks that lenders and investors see with new technologies and business models.

\footnotetext{
${ }^{79}$ Building Blocks document provided by USAID GCC office. References within document were not provided when USAID issued the document.

${ }^{80}$ Areas with better solar or wind resources result in a higher percentage of operation of RE plants. This is called

"capacity factor", and is basically the percentage of time that a unit is actually generating electricity.
} 
Part of the objectives of a national CE program must be to drive down prices. That is on the minds of planners and policy makers in most of the countries that are scaling up. Using these building blocks is associated with measurable price reductions and rapid increases in RE deployment.

F. Climate planning: USAID has not issued guidance on this building block as of the writing of this report. 


\section{Appendix IV: Grid Integration Check List for Mexico ${ }^{81}$}

\section{Mexico-specific Checklist of Recommendations: Input Data}

Recommendations for Mexico on input data for grid integration studies include:

- Leverage existing and forthcoming solar radiation time series data for Mexico to estimate sub-hourly solar power variations for desired locations and deployment scenarios. Invest early in the development of a large-scale mesoscale weather model to predict wind speeds across Mexico's geography. Calibrate this model using data from entities such as IIE, SENER, international wind developers, public and private weather modelers, and public data measurement methods.

- As an alternative to developing a mesoscale wind model specifically for GOM, explore developing an agreement between SENER and Vestas that would allow the use of Vestas's proprietary mesoscale model results in SENER's broad-scale integration studies. This route could potentially save significant time and money and thereby significantly shorten the grid integration analysis time window.

- Participate in the UVIG annual forecasting workshop and similar venues to gain insight into the evolution of wind and solar forecast methodologies. Consider expanding Mexico's representation in IEA Wind to include participation in Task 25 by appropriate representatives from SENER, CENACE, CFE, and IIE. While beyond the scope of this roadmap, IIE and other Mexico stakeholder concerns regarding distribution system impacts of rooftop and other customer sited PV systems have been examined and addressed in the IEA Photovoltaic Power Systems Programme (PVPS) Task 14 on High Penetration of PV Systems in Electric Grids. Mexico is part of the PVPS, but expanding active participation into Task 14 activities is recommended.

- Tie unit commitment and economic dispatch modeling analysis and related input data requirements to the reforms being considered in the post-reform wholesale market (e.g., the time intervals relevant to forecasting errors should match unit commit reschedule and gate closure times).

- Ensure interconnection agreements and PPAs with independent power producers include requirements to provide forced outage data and real-time generation and metrological conditions to inform centralized forecasting by grid operators.

- Develop requirements for self-generators to provide performance data and forecasts to grid operators to inform centralized forecasting, grid integration scenario development, and resource modeling.

- Consider revising grid codes to reflect expectations for wind turbine capabilities. In the near term, these capabilities might include fault ride-through, provision of reactive power, and possibly AGC. In the longer term, capabilities might include inertial response and primary frequency response.

\footnotetext{
${ }^{81}$ Parson, Brian et al., "Renewable Electricity Grid Integration Roadmap for Mexico: Supplement to the IEA Expert Group Report on Recommended Practices for Wind Integration" (National Renewable Energy Lab, December 2014)
} 
- IIE commented that CENACE has an informational database with historical hourly demand forecasts and actual demand by control area. If possible, begin archiving sub-hourly data.

- For integration studies that look 20-30 years in the future, consider including demand scenarios beyond simply the uniform projection of historic load, such as those that account for electrification of cars, energy efficiency, or different growth rates.

- Given concerns regarding the dispersed nature of the Mexican transmission system, evaluate the need to use nodal representation for transmission analysis as an alternative to standard "copper plate" assumptions (which may ignore transmission limitations).

- Expand load flow transmission scenario cases beyond the traditional worst-case snapshot transmission cases to examine additional temporally coincident cases that screen for a variety of wind and solar power delivery and electric load combinations.

- Use the developed wind and solar historic variability datasets for composite wind and solar output (rather than simply the total nameplate output of all plants) to assess possible renewable curtailment due to transmission limitations.

- IIE commented that existing CENACE datasets in its short-term planning model contain fossil plant performance factors such as ramp rates, minimum generation levels, heat rates as a function of load, minimum up times and minimum down times. It is necessary to enhance combined cycle plant data related to dead zones, feasible transitions between configurations, and minimum and maximum time that plants must remain on a certain configuration.

- CENACE databases contain detailed data of both hydroelectric plant models and hydroelectric systems. It is, however, necessary to update some of these data in order to improve the results of the flexibility studies.

- Mexico could consider developing data on demand response supply curves for production cost models to evaluate as a potential mitigation measure to reduce integration costs, particularly if conventional plant flexibility is insufficient or wind and solar curtailment levels are excessive.

\section{References}

Ackermann, T.; Ellis, A.; Fortmann, J.; Matevosyan, J.; Muljadi, E.; Piwko, R.; Pourbeik, P.; Quitmann, E.; Sorensen, P.; Urdal, H.; Zavadil, B. (2013). "Code Shift: Grid Specifications and Dynamic Wind Turbine Models." Power and Energy Magazine, IEEE (11:6); pp. 72-82. Accessed October 2014: http://ieeexplore.ieee.org/stamp/stamp.jsp?tp=\&arnumber=6634510.

Bird, L.; Cochran, J.; Wang, X. (2014). "Wind and Solar Energy Curtailment: Experience and Practices in the United States." NREL/TP-6A20-60983. Golden, CO: National Renewable Energy Laboratory. Accessed October 2014: http://www.nrel.gov/docs/fy14osti/60983.pdf. 
Braun, M.; Stetz, T.; Brundlinger, R.; Mayr, C.; Hatta, H.; Kobayashi, H.; Ogimoto, K.; Kroposki, B.; Mather, B.; Coddington, M.; Lynn, K.; Graditi, G.; Woyte, A.; MacGill, I. (2011). "Is the Distribution Grid Ready to Accept Large Scale Photovoltaic Deployment? - State of the Art, Progress and Future Prospects." 26th European Photovoltaic Solar Energy Conference: Proceedings of the International Conference, 5-9 September 2011, Hamburg, Germany. Munich, Germany: WIP-Renewable Energies pp. 3840-3853; NREL/CP-6A00-54390. Accessed September 2014: http://dx.doi.org/10.4229/26thEUPVSEC2011-5DP.3.1.

Braun, M.; Stetz, T.; Brundlinger, R.; Mayr, C.; Ogimoto, K.; Hatta, H.; Kobayashi, H.; Kroposki, B.; Mather, B.; Coddington, M.; Lynn, K.; Graditi, G.; Woyte, A.; MacGill, I. (2012). "Is the Distribution Grid Ready to Accept Large-Scale Photovoltaic Deployment? State of the Art, Progress, and Future Prospects." Progress in Photovoltaics: Research and Applications Special Issue: 26th EU PVSEC, Hamburg, Germany, 2011. 20 (6); pp. 681-697; NREL/JA-6A00-57003. Accessed August 2014:

http://dx.doi.org/10.1002/pip.1204.

Cochran, J.; Bird, L.; Heeter, J.; Arent, D. J. (2012). Integrating Variable Renewable Energy in Electric Power Markets: Best Practices from International Experience.

NREL/TP-6A20-53732. Golden, CO: National Renewable Energy Laboratory.

Cochran, J.; Lew, D.; Kumar, N. (2013). "Flexible Coal: Evolution from Baseload to Peaking Plant." NREL/BR-6A20-60575. Golden, CO: National Renewable Energy Laboratory. Accessed October 2014: www.nrel.gov/docs/fy14osti/60575.pdf.

Denholm, P.; Jorgenson, J.; Hummon, M.; Palchak, D.; Kirby, B.; Ma, O.; O'Malley, M. (2013a). Impact of Wind and Solar on the Value of Energy Storage. NREL/TP-6A2060568. Golden, CO: National Renewable Energy Laboratory.

Denholm, P.; Jorgenson, J.; Hummon, M.; Jenkin, T.; Palchak, D.; Kirby, B.; Ma, O.; O'Malley, M. (2013b). Value of Energy Storage for Grid Applications. NREL/TP-6A2058465. Golden, CO: National Renewable Energy Laboratory.

Denholm, P.; Wan, Y. H.; Hummon, M.; Mehos, M. (2014). "Value of CSP with Thermal Energy Storage in the Western United States." Energy Procedia - Proceedings of the SolarPACES 2013 International Conference, 17-20 September 2013, Las Vegas, Nevada. 1622-1631. NREL/CP-6A20-60027. Accessed October 2014: http://dx.doi.org/10.1016/j.egypro.2014.03.171.

Hummon, M.; Weekley, A.; Searight, K.; Clark, K. (2013). Downscaling Solar Power Output to 4-Seconds for Use in Integration Studies: Preprint. NREL/CP-6A20-60335. Accessed November 2014: http://www.nrel.gov/docs/fy14osti/60335.pdf.

Hummon, M.; Ibanez, E.; Brinkman, G.; Lew, D. (2012). Sub-Hour Solar Data for Power System Modeling From Static Spatial Variability Analysis:Preprint. NREL/CP-6A2056204. Accessed November 2014: http://www.nrel.gov/docs/fy13osti/56204.pdf. 
Hummon, M.; Kiliccote, S. (2014). "DR Resources for Energy and Ancillary Services in the West." NREL/PR-6A20-60165. Golden, CO: National Renewable Energy Laboratory.

Kumar, N.; Besuner, P.; Lefton, S.; Agan, D.; Hilleman, D. (2012). Power Plant Cycling Costs. NREL/SR-5500-55433. Golden, CO: National Renewable Energy Laboratory. Accessed October 2014: www.nrel.gov/docs/fy12osti/55433.pdf.

Lew, D.; Brinkman, G.; Ibanez, E.; Florita, A.; Heaney, M.; Hodge, B-M.; Hummon, M.; Stark, G.; King, J.; Lefton, A.; Kumar, N.; Agan, D.; Jordan, G.; Venkataraman, S. (2013). The Western Wind and Solar Integration Study Phase 2. NREL/ TP-550055588. Accessed November 2014: http://www.nrel.gov/docs/fy13osti/55588.pdf.

North American Electric Reliability Corporation. (2010). "NERC IVGTF Task 2.1 Report: Variable Generation Power Forecasting for Operations." Princeton, NJ: NERC.

Accessed October 2014: http://variablegen.org/wpcontent/uploads/2013/01/Variable Generation Power Forecasting for Operations.pdf.

Porter, K.; Rogers, J. (2010). "Status of Centralized Wind Power Forecasting in North America." NREL/SR-550-47853. Golden, CO: National Renewable Energy Laboratory. Accessed October 2014: www.nrel.gov/docs/fy10osti/47853.pdf.

"Wind Forecast Improvement Project (WFIP)." (undated). Washington, DC: NOAA. Accessed September 2014: www.esrl.noaa.gov/psd/psd3/wfip/.

Mexico-specific Checklist: Portfolio Development and System Management

Recommendations for Mexico on portfolio development and system management include:

- Adapt and exercise a capacity expansion planning tool specific to Mexico that enables the exploration of potential wind and solar plant locations and captures the associated transmission costs to estimate the costs of meeting Mexico's RE targets. ReEDS and RPM are specific examples of existing models developed by NREL that could be adapted to or expanded for Mexico's use.

IIE commented:

"CFE has three models developed by the IIE, which could be used for this type of studies:

1) Long-term planning of generation expansion model (PEGyT, utilized by the Under director's office for Programming at CFE) which makes decisions about lowest total cost of investment, operation and externalities;

2) Multi-year stochastic dispatch model (utilized by the Market Operation Office at CENACE); and

3) Hydrothermal Coordination and Unit Commitment (CHT, utilized by the office of Market Operation at CENACE, previously described)." 
In response to this comment, the Roadmap authors agree with IIE that,

"The current models that CFE uses have some advantages over the NREL models. The CFE models use with certain sufficient details, the characteristics of the hydroelectric power plants, the storage capacity of the reservoirs, the configuration of the waterways, the spending restrictions in waterways, and the operating limitations of the reservoirs, and the uncertainty of the hydrologic runoffs, which for Mexico are relevant. Additionally, the three models currently utilized by CFE have the information of the various generation and transmission elements of the National Electric System, the storage network, and fuel transport system, already loaded and debugged."

The challenge is in assessing the most expedient course. Options include: 1) translating Mexico-specific electric grid data and practices into models that were developed specifically to account for the unique temporal, stochastic, and spatial characteristics of weather-driven wind and solar generation resources; or 2) adapting existing Mexico specific models that contain relevant existing system characteristics to capture the salient RE characteristics and concerns.

Past international experience shows base assumptions can have a large impact, possibly unintentionally. Areas we recommend be examined critically in existing Mexico specific planning models include:

- Year-to year RE resource variations;

- Maximum potential ceilings for renewable energy, by year;

- Minimum generation from clean energy, by year; and

- Stochastic behavior of renewable energy.

Translating system specific data and practices into models that are specifically designed to evaluate systems with high penetrations of wind and solar is more expedient and accurate in the long run.

\section{Checklist continued:}

- Consider modeling at least two scenarios for oil-fired power plant replacements: one where the highest efficiency gas plants dominate, and another that prioritizes gas plants designed to ramp quickly.

- Develop alternative wind and solar generation expansion scenarios to examine operational cost differences (e.g., centralized solar versus distributed generation, expanding transmission to remote energetic sites versus minimizing transmission expansion costs).

- Include operational reforms such as shifting to sub-hourly dispatch, integrating forecasting into unit commitment decisions, and instituting dynamic reserve practices into production cost modeling. Grid operational specialists from CENACE, grid planners from CFE, market reform and design specialists from SENER and CRE, and other relevant stakeholders can design the relevant scenarios.

- For higher rates of renewable energy $(>10 \%)$, if the production cost simulations suggest that reliability cannot be cost-effectively achieved based on the modified practices described above, consider additional sources of flexibility (e.g., demand control). 
- Use production cost modeling to quantify the effects of choosing different timesteps for dispatch and market operations to inform the ISO's development of operating rules and ancillary service markets for procuring reserves. Plexos commercial software, and, according to IIE, the existing IIE/CFE Hydrothermal Coordination model have this capability.

- Due to Mexico's relatively high anticipated annual electric load growth, give special attention to defining scenarios for the future generation mix that take into consideration planned additions, retirements, and future flexibility capabilities. The definition of scenarios is part of the current activities of the Subdireccion de Programacion para la elaboracion (Under Director of Programming in the elaboration of the Electric Sector Project and Investment Program - POISE).

- Define and maintain a constant acceptable loss of load expectation due to insufficient operational reserves across all modeling scenarios to ensure comparability of results.

- Given the potential impact of reserve practices on operational costs, consider examining the most up-to-date methodologies for dynamic reserve analyses.

\section{References}

Cochran, J.; Bird, L.; Heeter, J.; Arent, D. A. (2012). Integrating Variable Renewable Energy in Electric Power Markets: Best Practices from International Experience. NREL/TP-6A20-53732. Golden, CO: National Renewable Energy Laboratory. Accessed September 2014: www.nrel.gov/docs/fy12osti/53732.pdf.

Cochran, J.; Lew, D.; Kumar, N.(2013). "Flexible Coal: Evolution from Baseload to Peaking Plant." NREL/BR-6A20-60575. Golden, CO: National Renewable Energy Laboratory. Accessed September 2014: www.nrel.gov/docs/fy14osti/60575.pdf.

Cochran, J.; Miller, M.; Milligan, M.; Ela, E.; Arent, D.; Bloom, A.; Futch, M.; Kiviluoma, J.; Holttinen, H.; Orths, A.; Gómez-Lázaro, E.; Martín-Martínez, S.; Kukoda, S.; Garcia, G.; Møller Mikkelsen, K.; Yongqiang, A.; Sandholt, K. (2013). Market Evolution: Wholesale Electricity Market Design for 21st Century Power Systems. NREL/TP-6A2057477. Golden, CO: National Renewable Energy Laboratory. Accessed September 2014: www.nrel.gov/docs/fy14osti/57477.pdf.

Denholm, P.; Hand, M. (2011). "Grid Flexibility and Storage Required to Achieve Very High Penetration of Variable Renewable Electricity." Energy Policy (39:3); pp. 18171830. Accessed October 2014: www.sciencedirect.com/science/article/pii/S0301421511000292.

Holttinen, H.; Tuohy, A.; Milligan, M.; Lannoye, E.; Silva, V.; Muller, S.; and Soder, L. (2013). "The Flexibility Workout: Managing Variable Resources and Assessing the Need for Power System Modification." Power and Energy Magazine, IEEE (11:6); pp. 53-62. Accessed August 2014: http://ieeexplore.ieee.org/xpl/articleDetails.jsp?tp=\&arnumber=6634499\&searchWithin\% 3D.QT.flexibility+workout.QT.\%26queryText\%3Dpower+and+energy. 
Hummon, M.; Denholm, P.; Jorgenson, J.; Palchak, D.; Kirby, B.; Ma, O. (2013). Fundamental Drivers of the Cost and Price of Operating Reserves. NREL/TP-6A2058491. Golden, CO: National Renewable Energy Laboratory. Accessed September 2014: www.nrel.gov/docs/fy13osti/58491.pdf.

Mai, T.; Drury, E.; Eurek, K.; Bodington, N.; Lopez, A.; Perry, A. (2013). Resource Planning Model: An Integrated Resource Planning and Dispatch Tool for Regional Electric Systems. NREL/TP-6A20-56723. Golden, CO: National Renewable Energy Laboratory. Accessed Jan. 31, 2014: www.nrel.gov/docs/fy13osti/56723.pdf.

Miller, M.; Bird, L.; Cochran, J.; Milligan, M.; Bazilian, M.; Denny, E.; Dillon, J.; Bialek, J.; O'Malley, M.; and Neuhoff, K. (2013). RES-E-NEXT: Next Generation of RES-E Policy Instruments. NREL/TP-6A20-58882. Golden, CO: National Renewable Energy Laboratory. Accessed May 2014: http://iea-retd.org/wp-content/uploads/2013/07/RESE-NEXT IEA-RETD 2013.pdf.

Porter, K.; Mudd, C.; Fink, S.; Rogers, J.; Bird, L.; Schwartz, L.; Hogan, M.; Lamont, D.; and Kirby, B. (2012). Meeting Renewable Energy Targets in the West at Least Cost: The Integration Challenge. Denver, CO: Western Governors' Association. Accessed August 2014: www.westgov.org/policies/doc download/1602-meeting-renewableenergy-targets-in-the-west-at-least-cost-the-integration-challege.

Short, W.; Sullivan, P.; Mai, T.; Mowers, M.; Uriarte, C.; Blair, N.; Heimiller, D.; Martinez, A. (2011). Regional Energy Deployment System (ReEDS). NREL/TP-6A20-46534. Golden, CO: National Renewable Energy Laboratory. Accessed September 2014: www.nrel.gov/docs/fy12osti/46534.pdf.

\section{Mexico-specific Checklist: Capacity Value}

- Evaluate capacity value and resource adequacy of future scenarios as a prescreen to the more detailed PCM evaluation. If adequacy criteria are not met, revise scenarios to increase generation or decrease load before detailed PCM proceeds.

- Use high temporal and spatial resolution data, if available, to calculate capacity value. If a high resolution wind resource dataset is not yet available, commercially available lower resolution (and lower-cost) datasets may be used for the purpose of pre-screening.

\section{Mexico-specific Checklist of Recommendations: Production Cost Simulations and Flexibility Assessment}

Recommendations for Mexico on production cost simulations and flexibility assessment include:

- For initial integration analysis in Mexico, focus on operational rules addressing 1) sub-hourly UCED, 2) examination of reserve levels, and 3) dynamic reserve procurement. In future integration analyses, Mexico can consider including longer-term operational items, such as enlarging the balancing footprint through increased exchange with adjacent power systems. 
- For initial integration analysis, prioritize 1) incorporating wind forecasting into UCED, 2) accurate representation of fossil and hydro fleet characteristics, and 3) evaluation of wind and solar power curtailment levels when generator flexibility is fully utilized.

- Begin the UCED analysis without considering transmission power flow constraints. Evaluate the results against known constraints to determine if iteration back to limit delivery of ancillary services in the UCED modeling is needed.

- If initial or future integration evaluations indicate excessive curtailment (due to operational limits, rather than abnormal disturbance response needs) within the system, iterate to assess additional operational and physical sources of flexibility beyond those already suggested. Voluntary demand control programs, incentivizing future generation resources for flexibility, tapping hydro or gas storage opportunities, or adding electrical storage technologies can be examined once first round analyses are completed.

- Perform initial models for unit commitment and dispatch on a platform that accommodates sub-hourly time steps. Standardized tools from commercial vendors will readily capture the appropriate generator characteristics and UCED processes, but data development will be required. Existing tools in use in Mexico may be customizable to accommodate this type of analysis. We understand that the Hydrothermal Coordination model is currently being adapted to accommodate sub-hourly time steps and associated operational practices. Data for demand and generation forecasts may also require modification.

- Begin dataset development (critically, for wind resource time series and conventional generator capabilities) and scenario development as soon as feasible to enable timely implementation of the more detailed UCED modeling.

\section{References}

Bakke, J.; Zhou, Z.; and Mudgal, S. (undated). Manitoba Hydro Wind Synergy Study. Midcontinent Independent System Operator. Accessed July 2014:

http://energyexemplar.com/wpcontent/uploads/publications/Manitoba $\% 20$ Hydro $\% 20$ Wind $\% 20$ Synergy $\% 20$ Study $\% 20 \mathrm{~F}$ inal\%20Report.pdf.

California Independent System Operator Corporation. (2010). Integration of Renewable Resources: Operational Requirements and Generation Fleet Capacity at 20\% RPS. Accessed September 2014: http://energyexemplar.com/wpcontent/uploads/publications/CAISO Study Using PLEXOS.pdf.

"Projects: Other Selected Projects." (undated). Energy+Environmental Economics (E3). Accessed October 2014: www.ethree.com/public projects/renewables portfolio standard.php.

Lannoye, E.; Flynn, D.; O’Malley, M. (2012). "Evaluation of Power System Flexibility." IEEE Transactions on Power Systems (27:2); pp. 922-931. Accessed October 2014: http://ieeexplore.ieee.org/stamp/stamp.jsp?arnumber=06125228. 


\section{Mexico-specific Checklist of Recommendations: Analyzing and Presenting Results}

Recommendations for Mexico on analyzing and presenting results of grid integration studies include:

- Compare different alternative energy future scenarios from economic, reliability, security, and environmental perspectives and report key assumptions underlying metrics such as costs, generation mix, emission rates, operational practices, and market structures.

- Present the results of sensitivity analyses to address and communicate limitations of integration studies resulting from the definition of assumptions.

- Involve Mexican grid experts and stakeholders, including CFE, IIE, CENACE, CRE, and SENER, in developing and validating inputs, analyses, and results of integration studies. A technical review committee may be an appropriate mechanism for such engagement. Review and adapt as appropriate the UVIG's "Principles for TRC Involvement" to the entire process of grid integration assessment in Mexico.

- Seek guidance as needed from the international expert community (e.g., IEA, NREL, UVIG staff) to provide input and feedback on Mexico's ongoing grid integration analysis efforts. 


\section{Appendix V: USAID RUTAS Program}

\section{Energy Sector Labor Market Assessment}

Nuevo León saw a surge of investment in the energy sector -- from 0 to $35 \%$ of direct foreign investment in just one year -- following the energy reform. Due to the importance of these investments, the current administration has created a new undersecretary of energy, which is working with newly arrived energy firms (Sanyo, Next Energy, Baker Hughes, GE Energy, Schneider Electric, Weatherford, Schlumberger) to form a cluster (anticipated in fall of 2015). RUTAS is developing a specialized labor market assessment for the energy sector in Nuevo León in order to understand 1) how many jobs will be created over time, 2) what businesses will be hiring, and 3) what particular skills they will be looking for. To this end, RUTAS is consulting with the California Energy Commission after having conducted an initial labor market assessment consulting with the Secretary of Energy, the Mexican American Chamber, the British Council, the Financial Times, Bloomberg, the Autonomous University of Nuevo León, SENER, SEDECO NL, the Center for Energy Workforce Development and Texas A\&M. While information is still scarce regarding the quantitative and qualitative demand, RUTAS has begun to outline some initial findings:

- Nationally, $80 \%(108,000)$ of the direct employment opportunities related to energy reform will be for technicians, while only $20 \%$ will be for graduates from higher education.

- Given the fall in the price of oil, as well as the prolonged timeline of infrastructure development related to extraction, Nuevo León will not see significant job growth in the extractive sub-sector until at least 2024.

- While the state should expect an initial surge in infrastructure related jobs, these will likely disappear after the requisite infrastructure is installed.

- Similarly, depending on whether pipelines are built or not, the state could face a surge in logistics jobs that either drops off as pipelines come online or continues a steady rise.

- Finally, RUTAS anticipates accelerated growth in the renewable energy subsector, both among local and foreign firms. Given a prior reform that allowed companies to produce their own electricity, some private companies (e.g. Ternium and Cementos Mexicanos, or CEMEX) have a head start on energy production. In addition, new rules included in the energy reform will incentivize the development of clean energy sources (solar, wind, mini-hydraulic power, efficient cogeneration, nuclear and biomass). Business and industrial consumers will be obligated to purchase a percentage of their energy from clean energy providers. The most informed estimates put the percentage required in 2015 to fall somewhere between 10 and $25 \%$, in order to reach $35 \%$ by 2024 .

\section{Curriculum Alignment}

Once RUTAS confirms how many jobs will be created in which parts of the energy sector, the program will work with energy companies to define the critical skills they will hire for. Traditionally, the conversation between schools and industry was conducted on a superficial level, comparing job descriptions to graduate profiles. To ensure that 
businesses and schools are comparing apples to apples, RUTAS facilitates the conversation at a deeper level, comparing employer-defined skills to learning objectives in the existing curriculum. RUTAS' primary partner in our curriculum alignment work is CONALEP, The National College of Technical Professional Education, which alone among the technical upper secondary systems has sufficient curricular autonomy to add up to 270 hours of new learning objectives to any of its relevant degree programs. CONALEP offers combined college prep and vocational degree programs. Each threeyear degree program dedicates 1,530 hours to a common core academic and socioemotional skills curriculum (heavily weighted towards the first year and a half), 1,710 hours to vocational courses (beginning in the second semester and increasing in intensity through semester six), 270 hours to contextualized college prep courses related to the degree (90 hours in semesters four, five and six), and 270 hours to a technical specialty ( 90 hours in semesters four, five and six).

For example, working with CONALEP in Chihuahua, in just six months, RUTAS was able to add two technical specialties to the Industrial Electro-Mechanics degree program, which boosted the program's relevant hours to that state's growing aerospace industry from 700 hours with industry-critical learning objectives to 970 .

\section{Bi-national Collaboration}

Because Mexico's private energy sector is in the early stages of development, RUTAS is leveraging its support from USAID to access industry-defined skills and competency standards, curriculum and business intelligence from across the border. Comparing the Center for Energy Workforce Development's (CEWD) Competency Model2 to the Mexican common core curriculum and industrial degree programs, RUTAS found a broad match between curricular learning objectives and CEWD's competency standards across the first three fundamental competency areas defined by the energy sector in the US: 1) personal effectiveness, 2) academic competencies, and 3) workforce competencies. In addition, among a subset of industrial technical degree programs within the CONALEP system, RUTAS found comparable learning objectives to CEWD's industry-wide technical competencies, in electrical generation, transmission, and distribution. 